\title{
Review
}

\section{Glucose Variability: How Does It Work?}

\author{
Vadim V. Klimontov ${ }^{1, *(D)}$, Olga V. Saik ${ }^{1,2}$ and Anton I. Korbut ${ }^{1}$ (D) \\ 1 Laboratory of Endocrinology, Research Institute of Clinical and Experimental Lymphology-Branch of the \\ Institute of Cytology and Genetics, Siberian Branch of Russian Academy of Sciences (RICEL-Branch of \\ IC\&G SB RAS), 630060 Novosibirsk, Russia; saik@bionet.nsc.ru (O.V.S.); korbutai@niikel.ru (A.I.K.) \\ 2 Laboratory of Computer Proteomics, Federal Research Center Institute of Cytology and Genetics, \\ Siberian Branch of the Russian Academy of Sciences (IC\&G SB RAS), 630090 Novosibirsk, Russia \\ * Correspondence: klimontovvv@bionet.nsc.ru
}

Citation: Klimontov, V.V.; Saik, O.V.; Korbut, A.I. Glucose Variability: How Does It Work? Int. J. Mol. Sci. 2021, 22, 7783. https://doi.org/10.3390/ ijms22157783

Academic Editor: Ramzi Ajjan

Received: 1 July 2021

Accepted: 17 July 2021

Published: 21 July 2021

Publisher's Note: MDPI stays neutral with regard to jurisdictional claims in published maps and institutional affiliations.

Copyright: (c) 2021 by the authors. Licensee MDPI, Basel, Switzerland. This article is an open access article distributed under the terms and conditions of the Creative Commons Attribution (CC BY) license (https:// creativecommons.org/licenses/by/ $4.0 /)$.

\begin{abstract}
A growing body of evidence points to the role of glucose variability (GV) in the development of the microvascular and macrovascular complications of diabetes. In this review, we summarize data on GV-induced biochemical, cellular and molecular events involved in the pathogenesis of diabetic complications. Current data indicate that the deteriorating effect of GV on target organs can be realized through oxidative stress, glycation, chronic low-grade inflammation, endothelial dysfunction, platelet activation, impaired angiogenesis and renal fibrosis. The effects of GV on oxidative stress, inflammation, endothelial dysfunction and hypercoagulability could be aggravated by hypoglycemia, associated with high GV. Oscillating hyperglycemia contributes to beta cell dysfunction, which leads to a further increase in GV and completes the vicious circle. In cells, the GV-induced cytotoxic effect includes mitochondrial dysfunction, endoplasmic reticulum stress and disturbances in autophagic flux, which are accompanied by reduced viability, activation of apoptosis and abnormalities in cell proliferation. These effects are realized through the up- and down-regulation of a large number of genes and the activity of signaling pathways such as PI3K/Akt, NF- $k B$, MAPK (ERK), JNK and TGF- $\beta /$ Smad. Epigenetic modifications mediate the postponed effects of glucose fluctuations. The multiple deteriorative effects of GV provide further support for considering it as a therapeutic target in diabetes.
\end{abstract}

Keywords: diabetes; hyperglycemia; hypoglycemia; glucose variability; complications; gene; epigenetic; signal pathways

\section{Introduction}

The concept of glucose variability (GV) is gaining increasing attention from scientists and clinicians. In recent decades, various methodological approaches have been developed to assess fluctuations in glucose levels [1,2]. Some GV metrics are implemented in the standardized analysis of continuous glucose monitoring (CGM) data [3]. The minimization of GV is recognized as a therapeutic target in diabetes management [4,5]. The growing attention to $\mathrm{GV}$ is explained primarily by the predictive value of this phenomenon. Many observational studies and post hoc analyses of randomized clinical trials have demonstrated that short-term GV and variability of glycated hemoglobin A1c $(\mathrm{HbA} 1 \mathrm{c})$ are associated with an increased risk of diabetic microvascular and macrovascular complications [6-11]. Some studies have also documented the association between high GV and mortality rates in patients with type 2 diabetes (T2D) $[4,10,12]$. Accumulating data indicate that ambient hyperglycemia can be even more dangerous for the cells of the cardiovascular and nervous systems, and renal and pancreatic beta cells than persistently high glucose levels [13-18]. The molecular pathways of the GV effect have been partially discovered in recent years and must be systematized.

In this review, we summarize data on GV-related biochemical/pathophysiological, cellular and molecular events in conditions of high GV, which may be important for the 
development of diabetic complications. We consequently searched the relevant articles in Pubmed/MEDLINE, Scopus and the Web of Science with the following keywords: "glucose variability" or "glycemic variability", "glucose fluctuation" or "glycemic fluctuation", "glucose excursion" or "glycemic excursion", "glucose oscillations" or "glycemic oscillations", "intermittent high glucose", "fluctuating glucose". We also combined these terms with "hypoglycemia". Reference lists of relevant reviews and articles were thoroughly checked to ensure all relevant studies were obtained. Both experimental and clinical studies were reviewed.

\section{Biochemical and Pathophysiological Abnormalities Induced by Excessive Glucose Fluctuations}

\subsection{Oxidative Stress and Non-Enzymatic Glycation}

It is generally accepted that hyperglycemia induces the overproduction of reactive oxygen species (ROS) and impairs the endogenous antioxidant defense, a condition known as oxidative stress. A number of experimental studies have indicated that intermittently high glucose (IHG) can generate even more severe oxidative stress than a constantly high glucose (CHG) level. Specifically, this effect was described in cultured endothelial cells [13,19-21], podocytes [22], adipocytes [23], Schwann cells [14,15] and pancreatic beta cells [24]. The effect of IHG was related to the enhanced activation of nicotinamide adenine dinucleotide phosphate (NADPH) oxidase [13] and included excessive ROS production, oxidative DNA damage and the depletion of superoxide dismutase activity $[19,20]$. An increase in plasma levels of malondialdehyde and 8-isoprostaglandin, well-known oxidative stress markers, as well as the enhanced generation of ROS in vascular endothelial cells, was demonstrated in rats with blood glucose fluctuations $(5.5-20 \mathrm{mmol} / \mathrm{L})$ induced by intermittent intravenous glucose infusion [25]. In patients with T2D, the levels of 8-isoprostaglandin F2 $\alpha$, thiobarbituric acid-reactive substances and 8-hydroxydeoxyguanosine showed positive correlations with the mean amplitude of glucose excursions (MAGE), but not with the $\mathrm{HbA} 1 \mathrm{c}$ level. Long-term GV, estimated by the standard deviation (SD) of $\mathrm{HbA1c}$ levels over a 2-year period, was also correlated with these oxidative stress markers [26]. Meanwhile, in other studies, no association between the urinary excretion of 8-iso-prostaglandin-F2 $\alpha$ and CGM-derived GV parameters was revealed in patients with type 1 diabetes [27] and well-controlled T2D [28]. Recent research has indicated a correlation between 1,5-anhydroglucitol, an intermediate-term marker of GV, and ROS metabolites in patients with T2D and $\mathrm{HbA} 1 \mathrm{c}$ below $8 \%$ [29].

A growing body of evidence indicates the role of GV as a predictor of hypoglycemia $[10,30,31]$. The alternation of hyperglycemic and hypoglycemic episodes, a characteristic feature of increased GV, can be a powerful inducer of oxidative stress. It was demonstrated that an episode of $2 \mathrm{~h}$ of hyperglycemia, followed by the recovery from the induced $2 \mathrm{~h}$ of hypoglycemia, aggravates oxidative stress in both healthy subjects and patients with type 1 diabetes (T1D) [32,33].

In diabetic conditions, hyperglycemia promotes the accumulation of advanced glycation end-products (AGEs). The activation of AGE receptors can lead to oxidative stress, low-grade inflammation and other events contributing to vascular complications [34]. However, little is known about the role of GV in the formation of AGEs. It was demonstrated that, among subjects with prediabetes, the levels of nitrotyrosine, a marker of nitrosative stress, and glyceraldehyde-derived AGEs were higher in those with increased MAGE [35,36]. Recent data indicate that acute glucose fluctuations up-regulate the expression of the receptor for AGEs in rat podocytes [37].

At present, oxidative stress and non-enzymatic glycation are considered as the mechanisms of "metabolic memory", which determine the extent of the effect of glycemic control on metabolism and clinical outcomes in diabetes [35,36]. It was shown that the increased production of ROS in cultured human endothelial cells, caused by an excess of glucose ( $30 \mathrm{mmol} / \mathrm{L}$ ), persists for at least a week after the normalization of glucose levels [38]. The incubation of human umbilical vein endothelial cells (HUVECs) in conditions of CHG ( $25 \mathrm{mmol} / \mathrm{L}$ ) or IHG ( $24 \mathrm{~h}$ in $5 \mathrm{mmol} / \mathrm{L}$, followed by $24 \mathrm{~h}$ in $25 \mathrm{mmol} / \mathrm{L}$ ) for 2 weeks 
resulted in the up-regulation of ROS production. The generation of ROS was increased a week after the normalization of glucose levels, especially in cells that were previously incubated with IHG. Therefore, the memory effect can be more pronounced in high-GV conditions [37].

\subsection{Chronic Low-Grade Inflammation}

The activation of inflammatory pathways plays an important role in the pathogenesis of diabetic complications [39,40]. Increased GV contributes to the inflammatory response. As compared to $\mathrm{CHG}$, oscillating glucose was a more potent inducer of intercellular adhesion molecule 1 (ICAM-1), vascular cell adhesion molecule 1 (VCAM-1), E-selectin and interleukin 6 (IL-6) expression in HUVECs. This effect was related to the oxidative stress and activation of poly (ADP-ribose) polymerase and protein kinase C [41,42]. The exposure to IHG enhanced the secretion of IL-6 and tumor necrosis factor $\alpha$ (TNF- $\alpha$ ), the inflammatory cytokines, by activated monocytes; this effect was partly attributable to the inherent osmotic stress [43]. The expression and secretion of interleukin 18 (IL-18) in mouse peritoneal macrophages were increased to a greater extent under the influence of IHG than CHG; this effect was mediated by the c-Jun N-terminal kinase (JNK) signaling pathway [44]. In rat podocytes, acute glucose fluctuations induced the expression of TNF- $\alpha$ and interleukin 1 beta (IL-1 $\beta$ ) to a greater extent than CHG [22]. In adipocytes, IHG induced a greater increase in the expression and secretion of IL-18 and monocyte chemoattractant protein 1 (MCP-1) than CHG [23]. An inflammatory response to fluctuating glucose has also been demonstrated in vivo. In rats, blood glucose fluctuations induced by intermittent glucose infusions increased the expression of IL-6, TNF- $\alpha$ and ICAM- 1 in vascular endothelial cells [25].

Hypoglycemia may act as an additional trigger of inflammation under oscillating conditions. In cultured macrophages, the intermittent episodes of hypoglycemia and hyperglycemia (3-15 $\mathrm{mmol} / \mathrm{L}$ ) promoted M1 polarization and an inflammatory response, estimated by the secretion of integrin alpha X, IL- $1 \beta$, TNF- $\alpha$, IL- 6 and MCP-1, via a mechanism involving the Toll-like receptor 4 (TLR4)-interferon regulatory factor 5 (IRF5) pathway [45]. It was found that hypoglycemia promotes the mobilization of specific leukocyte subsets into the bloodstream and induces proinflammatory changes in the leukocytes in healthy individuals and patients with T1D [46]. Specifically, the mobilization of cluster of differentiation 8-positive (CD8+) T cells, cytotoxic natural killers and natural killer T cells, as well as non-classical monocytes, was observed [47]. In patients with T1D, an episode of two-hour hypoglycemia was followed by an increase in the levels of soluble ICAM-1 (sICAM-1) and IL-6 [48]. High blood glucose, replacing hypoglycemia, caused a further increase in the concentrations of sICAM-1 and IL-6 [49]. In T1D patients on pump therapy, the number of hypoglycemic episodes predicted plasma levels of ICAM-1, VCAM-1 and E-selectin [50]. In subjects with T1D, acute hyperglycemia was followed by an elevation in urinary excretion of a number of proinflammatory chemokines and cytokines [51]. In nondiabetic subjects with reactive hypoglycemia, Eik W. et al. observed a rise in the plasma levels of proinflammatory (IL-2, IL-5 and IL-17) and anti-inflammatory cytokines (IL-4, IL-1RA, IL-2R, IL-13 and fibroblast growth factor basic) during hypoglycemia after the glucose load [52]. An increase in adrenaline mediates the inflammatory response associated with hypoglycemia in non-diabetic subjects and patients with T1D [53].

Associations between inflammatory markers and GV have been observed in some clinical studies. A correlation between high-sensitivity C-reactive protein (hsCRP) levels and CGM-derived SD was reported in adolescents with T1D [54]. In patients with T2D, hsCRP correlated with both short-term (MAGE index) and long-term GV (SD of $\mathrm{HbA1c}$ level over two years) [26]. In another study, acid $\alpha_{1}$-glycoprotein, but not hsCRP, was related to GV indices reflecting hyperglycemic fluctuations in subjects with T2D [55]. An association between the coefficient of variation (CV), calculated from CGM data, and blood IL-6 levels was shown in non-diabetic persons with metabolic syndrome [56]. 


\subsection{Endothelial Dysfunction and Vascular Remodeling}

Endothelial dysfunction is considered as an important player in the pathogenesis of diabetic vascular complications. Hyperglycemia impairs the vascular endothelium function through the polyol and hexosamine pathways, protein kinase $\mathrm{C}$ (PKC) activation and generation of AGEs, all of which lead to ROS overproduction, the dysregulation of growth factors and cytokines and epigenetic changes [57]. A growing body of evidence indicates a deleterious effect of supraphysiological glucose fluctuations on endothelial function. When compared to CHG, IHG produced a stronger impairing effect on NO synthesis in cultured HUVECs [58]. Increased GV, even in the absence of high glucose levels, can suppress the endothelial defense against hyperglycemia-induced metabolic disorders. Modeling short-term fluctuations similar to those in diabetic patients changed the synthesis of a number of key enzymes in cultured human endothelial cells. Specifically, a decrease in the expression of superoxide dismutase 2, heme oxygenase 1 , glyoxalase and transketolase was observed [59]. It was demonstrated that IHG can promote vascular endothelial senescence to a greater extent than CHG, which is partially dependent on oxidative stress [60].

Horvath et al. compared the effect of stable and intermittent hyperglycemia on endothelial function in rats with streptozotocin-induced diabetes. The endotheliumdependent dilation was significantly impaired in rats that were periodically injected with insulin compared with animals that did not receive treatment, despite the lower mean blood glucose levels in the insulin-treated group [61]. In patients with T1D, glucose fluctuations in the range of $5-15 \mathrm{mmol} / \mathrm{L}$ induced a more severe impairment of endothelium-dependent arterial dilation compared to that induced by stable hyperglycemia (10 and $15 \mathrm{mmol} / \mathrm{L}$ ). The effect of intermittent hyperglycemia on endothelial function has been associated with oxidative stress [49]. In non-complicated T2D subjects receiving a diet and/or metformin, mean postprandial glucose excursions correlated negatively with flow-mediated arterial dilation [62]. Similarly, enhanced GV was related to flow-mediated dilation in patients with T2D and coronary artery disease [44]. In children with T1D, flow-mediated dilation was related to hypoglycemia, but not MAGE or other GV metrics [63]. It was found that endothelial microparticles, a novel surrogate marker of endothelial injury and dysfunction, are differentially produced in response to hypoglycemia in subjects with and without T2D. Insulin-induced hypoglycemia provoked a more dramatic increase in the levels of CD31+ and CD105+ endothelial microparticles in individuals with T2D compared to controls [64].

There are some data indicating endothelial dysfunction in individuals with impaired glucose tolerance, which can be considered as an equivalent to enhanced GV in nondiabetic subjects. It was reported that plasma levels of von Willebrand factor, and soluble E-selectin, two widely used markers of endothelial damage, are elevated in patients with impaired glucose tolerance [65]. In the population-based Maastricht Study, which enrolled 2758 participants, the glucose peak during a glucose tolerance test was independently associated with aortic stiffness and carotid remodeling, as well as with microvascular function, estimated by retinal arteriolar dilation and heat-induced skin hyperemia [66]. In subjects with T2D and unstable angina, the SD of blood glucose was an independent predictor for coronary artery calcification [67].

\subsection{Platelet Activation and Hypercoagulability}

The interactions between activated vascular cells and vulnerable atheromatous plaques are considered as a cornerstone in atherothrombotic burden in diabetes [68]. Some data indicate that enhanced GV could be related to platelet reactivity. Specifically, in patients with T2D, postprandial hyperglycemia was associated with platelet activation, estimated by the urinary excretion of 11-dehydro-thromboxane B2. The excretion rate was reduced by the treatment with acarbose, following earlier decreases in postprandial glucose and MAGE [69]. In subjects with well-controlled T2D via clopidogrel therapy, MAGE and CV provided independent and additional diagnostic significance in identifying patients with 
high platelet reactivity [70]. At the same time, no impact of acute glucose load (75 g) on platelet aggregation was observed in patients with T2D or acute coronary syndrome [71].

While the effect of hyperglycemic fluctuations on platelets warrants further research, the role of hypoglycemia in platelet activation and hypercoagulability is well established. In a study with hyperinsulinemic-hypoglycemic and euglycemic clamps, hypoglycemia mobilized monocytes, increased platelet reactivity and promoted the interaction between platelets and proinflammatory monocytes in healthy subjects [72]. In the study of Ceriello et al., hypoglycemia increased plasma levels of prothrombin fragment $1+2$, thrombinantithrombin III complexes and plasminogen activator inhibitor-1 (PAI-1) in both healthy subjects and people with diabetes. The transition from hypoglycemia to normoglycemia was accompanied by a significant improvement in coagulation parameters. On the contrary, hyperglycemia following hypoglycemia worsened coagulation markers; the effect persisted even after an additional $6 \mathrm{~h}$ of normoglycemia [33].

\subsection{Impaired Angiogenesis}

An angiogenic paradox has been described in diabetes, which refers to the excessive angiogenesis in retinopathy and nephropathy and suppression of blood vessel growth in limb and myocardial ischemia [73]. It was found that, according to this pattern, GV causes a bidirectional effect on angiogenesis. Acute glucose fluctuations (in the range of 5-25 mmol/L) impaired the proliferation of HUVECs and angiogenesis in vitro and delayed wound healing in mice. The effect of IHG on angiogenesis was more prominent than that of CHG [74]. In agreement with these data, the modeling of increased GV in mice impaired ischemia-induced angiogenesis in the hind limb by the suppression of vascular endothelial growth factor (VEGF) production [75]. At the same time, both CHG and IHG up-regulated VEGF in human retinal endothelial cells. The IHG effect on cell proliferation and VEGF expression was mediated via mitochondrial ROS overproduction [21].

The dysfunction and count abnormalities of endothelial progenitor cells (EPCs), which are derived from the bone marrow and involved in endothelial repair and new blood vessel formation, have been observed in diabetes [76]. The direct influence of IHG on EPCs has not been tested. Nonetheless, in patients with the T1D, the J-index, a GV parameter, correlated negatively with $\mathrm{CD} 34^{+} \mathrm{EPC}$ count [77]. In turn, reducing GV with continuous subcutaneous insulin infusion increased the EPC levels in subjects with T1D [78]. In patients with T1D, the levels of hematopoietic stem/progenitor cells $\left(\mathrm{CD} 34^{+} \mathrm{CD} 133^{+}, \mathrm{CD} 34^{+} \mathrm{CD} 45^{\mathrm{dim}}\right)$ were reduced and correlated positively with $\mathrm{CV}$ and time in hypoglycemia estimated by flash glucose monitoring; the relationships were mitigated in long-lasting diabetes [79].

\subsection{Renal Fibrosis}

More than half a century ago, it was shown that supraphysiological glucose fluctuations can induce renal lesions characteristic of diabetic nephropathy in rats [80]. Many years later, the biochemical aspects of this effect were identified. It was demonstrated that IHG (5-25 mmol/L) increases the production of collagen types I, III and IV in cultured mesangial cells, and type III collagen synthesis increases to a greater extent when stimulated by oscillatory glucose rather than CHG [81]. In proximal tubular cells, IHG was found to be a more potent stimulating factor for the secretion of transforming growth factor beta (TGF- $\beta 1$ ), one of the most powerful fibrogenic mediators. In both cortical fibroblasts and proximal tubular cells, IHG increases collagen synthesis [82]. In cortical fibroblasts, fluctuating glucose enhances the production of collagen IV and fibronectin. In addition, it increases the synthesis of tissue inhibitor of matrix metalloproteinase, inhibiting matrix degradation. A short-term $(90 \mathrm{~min}$ ) increase in the glucose concentration stimulates TGF- $\beta 1$ secretion by fibroblasts [83]. Thus, excessive glucose fluctuations can cause a more pronounced fibrogenic effect in a diabetic kidney than persistent hyperglycemia. This fact is consistent with data indicating that high GV is associated with a decline in renal function in diabetic rats [84] and patients with T2D [85,86]. 


\subsection{Beta Cell Dysfunction}

An inverse relationship between beta cell function and GV was observed in subjects with both T1D [87] and T2D [88,89]. Obviously, a compromised insulin response causes an increase in GV. At the same time, excessive GV can contribute to the progressive deterioration of beta cell function. It was found that IHG induces a more significant impairment of the glucose-stimulated insulin release response in rat islets and insulinoma cells (INS-1) than CHG, and this effect is related to the stress of the endoplasmic reticulum and oxidative stress [24]. When incubated under IHG conditions, INS-1 demonstrated a reduction in the response to glucagon-like peptide 1 [90]. In these cells, IHG generated a more toxic effect than CHG, including both apoptosis-inducing and antiproliferative activity [17]. A deteriorating effect of IHG on apoptosis and insulin release could be diminished by antioxidant pretreatment [91]. In rats, either continuous or intermittent hyperglycemia induced beta cell dysfunction and insulin resistance [25]. Chronic oscillating glucose caused beta cell dedifferentiation and failure in rats [67]. The long-term effect of enhanced GV on beta cell function and plasticity needs further research.

Thus, the role of supraphysiological glucose fluctuations in the pathogenesis of vascular complications of diabetes is realized through non-enzymatic glycation, oxidative stress, chronic low-grade inflammation, endothelial dysfunction, vascular remodeling, angiogenesis disorders, activation of blood cells (platelets and leukocytes), hypercoagulability and renal fibrosis (Figure 1). Some of these abnormalities are exacerbated by hypoglycemia, which is at an increased risk in patients with high GV. Finally, oscillating hyperglycemia contributes to beta cell dysfunction, which further increases GV and completes the vicious circle.

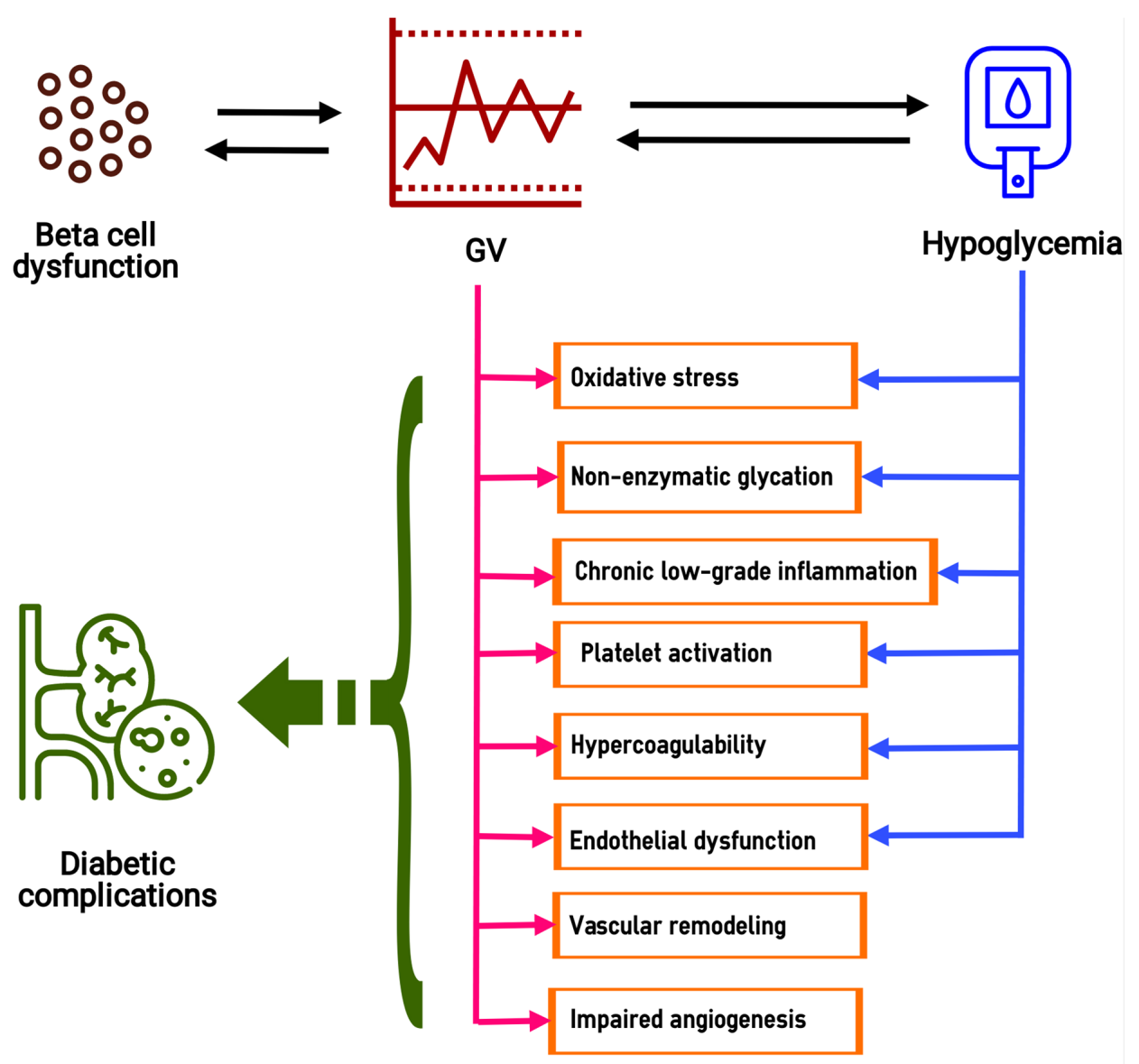

Figure 1. GV-related biochemical and pathophysiological abnormalities in the pathogenesis of diabetes complications. GV, glucose variability. The dotted lines in the GV block illustrate the excessive glucose oscillations. The green dashed arrow shows supposed relationships between pathophysiological processes, induced by high GV and hypoglycemia, and diabetic complications. 


\section{Cell Biology under High-GV Conditions}

\subsection{Altered Mitochondrial Homeostasis}

Abnormalities of mitochondrial biogenesis, fission, fusion and mitophagy are reported to be involved in impaired oxidation, reduced mitochondrial contents and excessive ROS production in diabetes [92]. Specifically, the signs of altered mitochondrial homeostasis and mitochondrial dysfunction were observed in the diabetic kidney [93], retina [94], heart [95] and pancreatic beta cells [96].

Mitochondrial dysfunction could be considered a cornerstone in the development of GV-related oxidative stress. In cultured HUVECs, oscillating glucose induced ROS generation and an altered mitochondrial membrane potential [97]. Similar changes were recorded in INS-1 cells under IHG conditions [98]. In astroglial cells, up and down glucose fluctuations induced mitochondrial dysfunction, which was accompanied by oxidative/nitrosative stress, impaired glutamate metabolism and increased proinflammatory cytokine secretion [99]. In hepatic L02 cells incubated with palmitic acid, IHG induced more pronounced oxidative stress and mitochondrial dysfunction compared to CHG. Treatment with cyclosporin A, a mitochondrial permeability transition inhibitor, prevented mitochondrial dysfunction, oxidative stress and hepatocyte apoptosis in a model of high GV in high-fat diet C57BL/6J mice [100]. In a model of ischemia/reperfusion injury in the diabetic heart, glucose fluctuations increased the levels of miRNA-200c and miRNA141. These changes were associated with decreased activities of mitochondrial superoxide dismutase and catalase and enhanced ROS production [101].

At present, little is known about the effect of GV on mitochondrial respiration and bioenergetics. It was demonstrated that in human islet cells, exposure to CHG for 4 days induced an increase in mitochondrial respiration and the cytosolicATP/ADP ratio [102]. Similarly, glucose fluctuations intensified aerobic glycolysis in cultured mouse mesangial cells. Oscillating glucose lowered the activity of aconitase, an enzyme of the Krebs cycle, and suppressed mitochondrial respiratory chain complex I [103]. At the same time, a reduction in the mitochondrial complex I activity was observed in the rat brain in a model of T1D [104]. Therefore, this effect may be induced by hyperglycemia per se, rather than increased GV. The role of glucose fluctuations in altering the mitochondrial respiratory chain requires further research.

\subsection{Endoplasmic Reticulum Stress}

The endoplasmic reticulum (ER) is considered to be important for nutrient sensing in many cell types, including hepatocytes, adipocytes, muscle cells, neurons and beta cells. An imbalance between the demand and capacity of the ER for protein folding is referred to as ER stress. Evidence is accumulating on the role of ER stress in the development of diabetes [105] and its complications, including retinopathy, nephropathy and neuropathy [106].

In diabetes, excessive glucose exposure alters ER homeostasis, and high GV may be an additional trigger for ER stress. It was demonstrated that in human retinal pericytes, IHG, but not CHG, increases the expression of activating transcription factor 4 (ATF4) and $\mathrm{C} / \mathrm{EBP}$ homologous protein (CHOP), key mediators of ER stress-associated inflammation and cell death [107]. In cultured rat pericytes, strong unfolded protein response activation leading to apoptosis was observed when glucose was reduced from high to low levels, or the zero level [108]. High GV turned out to be a more powerful inductor of ER stressrelated apoptosis compared with CHG in cultured rat vascular smooth muscle cells [67]. The modeling of recurrent short-term hypoglycemia and hyperglycemia induced apoptosis and oxidative stress via the response to ER stress in mouse Schwann cells [109]. In subjects with metabolic syndrome, the glucose load in the oral glucose tolerance test enhanced the expression of spliced XBP-1, Grp78 and calreticulin, the ER stress markers, in mononuclear cells. These changes were accompanied by a significant increase in the expression of inflammatory cytokines interleukin $1 \alpha / \beta$, IL-6 and interleukin 8 [110]. These data clearly indicate the role of glucose fluctuations in the generation of ER stress in diabetes. 


\subsection{Autophagy}

Autophagy is a process of self-degradation and reconstruction of damaged organelles and proteins via lysosomes. This cellular recycling is vital for highly differentiated cells, including neurons, podocytes, cardiomyocytes, retinal cells and beta cells [111,112]. The impaired autophagy plays a role in the development of both T1D and T2D [113-116], and diabetic kidney disease [117-119].

Glucose seems to be a prominent regulator of autophagy [120-122]. Glucose levels indirectly affect autophagy in many cell types through the regulation of glucagon and insulin secretion. Glucagon is known as a potent stimulator of autophagy, whereas insulin suppresses it by stimulating mammalian target of rapamycin complex 1 (mTORC1) [122]. In cells, glucose withdrawal causes ATP depletion, which stimulates AMP-activated protein kinase (AMPK) and the AMPK-S-phase kinase-associated protein 2 (SKP2)-coactivatorassociated arginine methyltransferase 1 (CARM1) signaling pathway, an upstream activator of autophagy [122-124]. On the other hand, impaired autophagy can influence insulin sensitivity through the changes in glucose transporter type 4 (GLUT4) degradation and recovery [125]. Moreover, impaired glycophagy, a selective autophagy in the liver, heart and muscles, could contribute to hyperglycemia [126].

It was shown that IHG causes enhancement of the autophagic flux in cultured HUVECs [74] and rat podocytes [22]. Similarly, in human retinal pigmented epithelial cells, IHG significantly increased the generation of autophagosomes, decreased the expression of an autophagy receptor, p62, a marker of suppressed autophagy, and induced the conversion of an autophagosome-associated protein microtubule-associated protein $1 \mathrm{~A} / 1 \mathrm{~B}$ light chain 3B (LC3) I to its active form LC3 II [127]. The role of GV in altering autophagy in vivo requires further research.

\subsection{Apoptosis}

The metabolic changes and dysfunction of organelles under high-GV conditions ultimately reduce the survival of a number of cells. Some in vitro studies have demonstrated the pro-apoptotic effect of IHG in endothelial cells [25,128,129], mesangial cells [103,130], cardiomyocytes [131], neurons [132,133], glial cells [134], Schwann cells [135] and beta cells $[98,136]$. The activation of GV-related apoptosis was attributed to mitochondrial dysfunction, ER stress and autophagy [100,124,127,131].

Glucose fluctuations have been validated to be more harmful than CHG in exacerbating the apoptosis of beta cells. In cultured INS-1, IHG induced apoptosis by the significant up-regulation of pro-apoptotic proteins caspase- 3 and 9 , and by down-regulation of the antiapoptotic protein Bcl-2 [98].

$\mathrm{Wu}$ N. et al. performed in vivo experiments demonstrating the effect of acute glucose fluctuations on the levels of apoptosis regulators in aorta endothelial cells in rats. Animals with glucose fluctuations induced by intermittent glucose infusions demonstrated reduced Bcl-2 and pro-caspase- 3 levels, and enhanced Bax mitochondrial translocation and caspase-3 p17 protein levels, in comparison with those with persistent hyperglycemia [25]. In the high-GV model established by insulin and glucose injections in rats with diet- and streptozotocin-induced diabetes, the predominance of pro-apoptotic regulators with an increased Bax/Bcl-2 ratio was found [84]. Interestingly, sodium-glucose cotransporter 1 (SGLT1) knockdown down-regulated Bax expression, up-regulated Bcl-2 expression and reduced caspase-3 activation induced by high GV in cultured rat H9c2 cardiomyocytes [131].

The activation of apoptosis is among the most important mechanisms of neurodegeneration in diabetes. It was shown that IHG induces the oxidative stress-related apoptosis of Schwann cells by both caspase-dependent and caspase-independent pathways. The cytotoxic effect of IHG was significantly more potent than that of CHG [14,15]. The central nervous system, being highly dependent on the glucose supply, becomes especially vulnerable in conditions of high GV. In diabetic rats, intermittent hyperglycemia turned out to be a more critical factor, promoting neuron apoptosis and inducing inflammation in the hippocampus, than CHG [132]. At the same time, acute glucose fluctuations affect 
microglial activity. It was demonstrated that a sharp increase in the glucose level (from 5.5 to $25 \mathrm{mmol} / \mathrm{L}$ ) promotes cell growth, induces oxidative and inflammatory stress and activates microglial cells. The reverse shift from hyperglycemia to normoglycemia trapped microglia in a state of metabolic stress, which triggered apoptosis and autophagy [134].

\subsection{Cell Proliferation}

Enhanced GV can modulate the proliferative response. It was found that either CHG or IHG induces the proliferation of vascular smooth muscle cells (VSMCs) in vitro [137]. Fluctuating glucose increased the proliferation and migration of VSMCs in an OLETF rat T2D model [138]. Earlier research demonstrated that IHG enhances cell proliferation and VEGF expression in retinal endothelial cells. These changes were associated with ROS overproduction at the mitochondrial transport chain [21].

At the same time, GV can suppress the proliferation of endothelial cells, podocytes and beta cells. Both IHG and CHG decreased the proliferation of cultured HUVECs [74]. It was revealed in INS-1 culture that IHG decreases beta cell viability and induces G0/G1 cell cycle arrest. INS-1 demonstrated a decreased expression of mitogen factors cyclin D1 and S-phase kinase-associated protein 2, whereas the expression of cyclin-dependent kinase inhibitors $1 \mathrm{~A}$ and $1 \mathrm{~B}$, two antiproliferative factors, was increased $[17,139]$.

Thus, high GV can promote many events in the targeted cells, including mitochondrial dysfunction, ER stress, changes in the intensity of autophagic flux, apoptosis activation and abnormalities in the proliferative response (Figure 2).

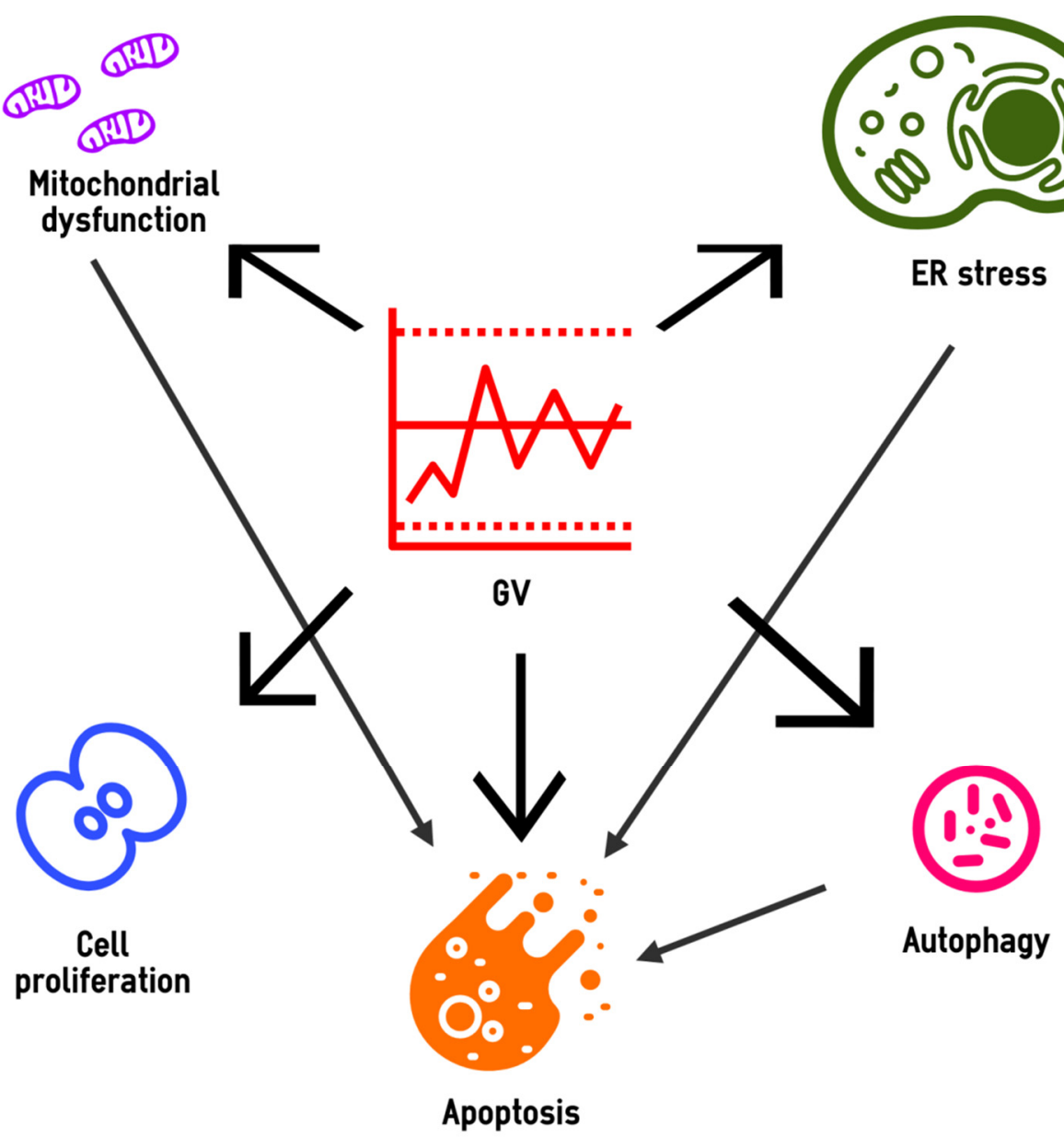

Figure 2. Cellular events promoting the high GV effects on target organs in diabetes. GV, glucose variability; ER, endoplasmic reticulum. The dotted lines in the GV block illustrate the high glucose excursions. The thick arrows show the cellular events induced by high GV, the thin arrows demonstrate the relationships between these events. 


\section{Molecular Mechanisms of the High GV Effects in the Target Cells \\ 4.1. Gene Expression}

Although there are scarce data on changes in gene expression induced by excessive $\mathrm{GV}$, there is a large pool of studies on gene profiling related to hyperglycemia. Using high-throughput technologies, differential gene expression was measured under hyperglycemic conditions in beta cells [140,141], pancreatic cells [142], hepatic cells [143,144], endothelial cells [145], myotubes [146], cardiomyocytes [147], vascular smooth muscle cells [148,149], adipose progenitor cells [150], kidney cells [151], renal tubular epithelial cells [152], retina [153,154], immune cells $[155,156]$ and others. The genes that demonstrate an altered expression in hyperglycemia are mostly involved in glucose metabolism, inflammation and immune processes, endothelial dysfunction, angiogenesis, oxidative stress, mitochondrial dysfunction, hypoxia and cell death.

Transcriptomic studies have revealed the effect of hyperglycemia on the expression profile of a large number of genes. More than 80 genes involved in hepatic lipid metabolism were differentially expressed in hyperglycemic rats with a model of T1D [143]. With the use of high-throughput RNA sequencing, it was demonstrated that hyperglycemia has a strong effect on HepG2 cells, with 4259 genes showing a differential expression. These genes participate in cholesterol metabolism, DNA replication, complement and clotting cascades [144]. Maier et al. hypothesized that hyperglycemia amplified the expression of genes induced by thrombospondin- 1 in vascular smooth muscle cells. Microarray analysis revealed that hyperglycemia altered the expression of 30 genes, while hyperglycemia combined with thrombospondin-1 altered the expression of 2822 genes. These findings suggest that hyperglycemia may significantly enhance the thrombospondin-1 effect on atherosclerosis progression [148].

Fewer studies have focused on gene expression in hypoglycemia. In sirtuin 6-deficient mice that developed a lethal early-life hypoglycemia, the microarray revealed nearly 200 genes with an altered expression. These genes were involved in glucose metabolism, nutrient stress responses, glycolysis and mitochondrial function [157]. A gene response to insulin-induced hypoglycemia was estimated in the mouse retina by an array. Genes whose expression was modified by low glucose were enriched in lysosomal function, glutathione metabolism and apoptotic pathways and potentially involved in retinal cell death [158]. A set of genes specifically activated by recurrent hypoglycemia was revealed in a study of whole genome expression profiling after recurrent hypoglycemia and acute hypoglycemia in the adrenal medulla of normal Sprague Dawley rats. These genes were related to the activation of the unfolded protein response, impaired epinephrine secretion, increased neuropeptide signaling, altered ion homeostasis and down-regulation of genes involved in $\mathrm{Ca}^{2+}$-dependent exocytosis of secretory vesicles [159].

It was found that even short-term enhanced GV could adversely affect gene expression in the arterial wall. In the study of Zervou et al., pIns-c-MycER(TaM) transgenic mice were successively exposed to hypo- and hyperglycemia, after which they recovered for up to 3 months. The expression of 95 genes was significantly affected by hypoglycemia, and 769 genes were affected by hyperglycemia. These genes were involved in atherogenic processes, including inflammation and arterial calcification. Although the expression of many genes returned to its initial level after 3 months, in one in four genes, recovery was not observed [160]. These data indicate that non-physiological glucose fluctuations may have a prolonged effect on gene expression. Further research in this direction is urgently needed.

Recently, we performed the bioinformatic reconstruction and analysis of the gene network of GV. The network consisted of 37 genes/proteins associated with both hyperglycemia and hypoglycemia. GV-related molecules were involved in glucose metabolism, intracellular signaling, cell proliferation and other biochemical/physiological processes; they were identified in the central positions of the gene networks of diabetic vascular complications [161]. 


\subsection{Epigenetic Modifications}

Glucose can induce a number of epigenetic modifications that significantly alter the functioning and vital activity of various cell types. In a pivotal work in this field, ElOsta et al. demonstrated that transient elevation in the glucose level causes long-lasting epigenetic changes in the NF- $\mathrm{kB}$ subunit $\mathrm{p} 65$ promoter in aortic endothelial cells in vitro and in non-diabetic mice. These changes were associated with an increased p65 gene expression that persisted for at least 6 days of subsequent normal glucose levels, and NF- $\mathrm{kB}$-induced increases in MCP-1 and VCAM-1 expression [162]. These data clearly indicate that epigenetic modifications may be an important mechanism in GV-induced vascular inflammation and dysfunction.

Costantino S. et al. found DNA hypomethylation and histone 3 acetylation on the p66 ${ }^{\text {Shc }}$ promoter of the SHC-transforming protein 1 gene (SHC1), resulting in gene overexpression, in patients with T2D. CGM-derived MAGE and postprandial glucose, but not $\mathrm{HbA1c}$, were associated with the epigenetic profile. The intensification of glycemic control over 6 months did not eliminate the changes [163]. The mechanism of p66 ${ }^{\text {Shc }}$-reduced CpG methylation could be related to methyltransferase DNA (cytosine-5-)-methyltransferase 3 beta (DNMT3b), an enzyme playing an important role in the maintenance of DNA methylation. Sirtuin 1 (SIRT1) could be involved in H3 deacetylation of p66 ${ }^{\text {Shc }}[163,164]$. In patients with T2D, the expression of DNMT3b and SIRT1 was inhibited compared to the control [163].

Recently, the effect of glucose on whole genome DNA methylation was studied in human retinal endothelial cells and HUVECs [165]. The lines were exposed to basal ( $5 \mathrm{mmol} / \mathrm{L}$ ) or high $(25 \mathrm{mmol} / \mathrm{L})$ glucose-containing media for variable lengths of time. When comparing the endothelial cells, incubated for 2 days versus 7 days, 17,354 and 128 differentially methylated CpGs in 88 and 8 differentially methylated regions were identified for HUVECs and retinal endothelial cells, respectively. Pathway enrichment analyses highlighted the involvement of regulators of embryonic development (i.e., HOX genes), TGF- $\beta$ signaling, bone morphogenetic protein (BMP) signaling, runt-related transcription factor 2 (RUNX2) transcriptional regulation and the complement cascade.

It was demonstrated that fluctuating glucose significantly decreased the phosphorylation of the endothelial nitric oxide synthase (eNOS) at Ser-1177 and increased the phosphorylation of JNK and p38, leading to the damage of vascular endothelial cells [166]. IHG lowered the phosphorylation levels of protein kinase B (v-akt murine thymoma viral oncogene homologue, Akt), AMPK and glycogen synthase kinase 3 beta (GSK3 $\beta$ ), influencing the function of endothelial cells and beta cells [19,91,167].

Small single-stranded non-coding RNAs (miRNAs) have been discussed as another method of epigenetic regulation. Aberrant miRNA expression is implicated in the pathogenesis of numerous diseases, including diabetes and its complications [168]. In HUVECs cultured under IHG conditions, 13 miRNAs were differentially expressed. miR-1273g-3p partially mediated the effect of IHG on the autophagy, migration and proliferation of HUVECs [74]. Another example of GV-induced miRNA-dependent changes is a phenotype polarization switch of microglia. In microglial cells, glucose fluctuations induce polarization transitions from M2 to M1. The M1 phenotype has proinflammatory effects and can be responsible for neuronal damage; in contrast, M2-polarized microglia can inhibit the inflammatory response and promote nerve repair. It was found that miR-124, miR-145, miR-146a and miR-711 are implicated in the M2 phenotype polarization of microglia, while miR-689 and miR-155 are involved in M1 polarization. In macrophages, miR-124 and miR-146a induced M2 phenotype polarization [169]. In the glucose fluctuation cell model, miR-129-3p suppressed glucose-mediated hippocampal neuronal damage. Specifically, miR-129-3p overexpression produced a dramatic reduction in calcium overload, ROS generation and an increase in antioxidant activity [170]. In cultured HUVECs, miR-1273g-3p mediates the effect of GV on autophagy and endothelial dysfunction [74]. In human endothelial cells, miR-185 and miR-21 were induced by oscillating glucose, leading to an impaired antioxidant response by the dysregulation of glutathione peroxidase 1 and superoxide 
dismutase 2 [97,171]. It was demonstrated that IHG induces the up-regulation of HIF- $1 \alpha$ and miR-210 in glomerular mesangial cells, which might play a pivotal role in the series of molecular events triggered by GV [22].

Thus, the effects of glucose fluctuations on gene expression can be exacerbated and prolonged by epigenetic modifications. At present, glucose-induced epigenetic modifications and related changes in the activity of signaling pathways are considered as an important mechanism of "metabolic memory" or "metabolic karma" in diabetes [168,172,173].

\subsection{Signaling Pathways}

The cellular and molecular effects of GV are realized through a variety of signaling pathways. The activation of PKC is among the initial molecular events under high-glucose conditions. PKC is a driver of numerous signal transduction cascades that regulate cell metabolism and plasticity. Among the downstream targets of PKC is NADPH oxidase that activates superoxide production and thus exacerbates oxidative damage [174].

A number of molecular effects of oxidative stress are mediated via NF- $k B$-dependent signaling pathways. NF- $\mathrm{KB}$ is a universal transcription factor that controls the expression of genes for the immune response, apoptosis and cell cycle. In diabetes, ROS, AGEs and angiotensin II induce an inflammatory response, endothelial dysfunction and renal fibrosis via the activation of NF- $\mathrm{kB}$. Accordingly, NF- $\mathrm{kB}$ is considered as a potential target in diabetic vascular complications [175]. As it has previously been mentioned, transient high glucose induces prolonged NF- $\mathrm{kB}$ activation in vascular endothelial cells [162]. The IHG-stimulated activation of NF- $\mathrm{KB}$ in cultured HUVECs down-regulated the expression of bcl-2, an antiapoptotic protein [176]. In vascular cells, glucose fluctuations promote the dysfunction of large-conductance, calcium-activated potassium channels via the overproduction of ROS and activation of PKC $\alpha / \mathrm{NF}-\mathrm{kB} / \mathrm{MuRF} 1$ signaling [177]. ROS-mediated NF- $\mathrm{KB}$ activation under high-GV conditions up-regulates the receptor for AGEs in podocytes [22].

The dysregulation of the phosphoinositide-3-kinase (PI3K)/Akt, mitogen-activated protein kinase (MAPK) and AMPK pathways is considered to be involved in altered glucose metabolism and related biochemical abnormalities in diabetes and high GV $[178,179]$. The $\mathrm{PI} 3 \mathrm{~K} /$ Akt signaling pathway, which is essential for cell survival and growth, plays an important role in preventing endothelial cell injury induced by high glucose. It was shown that IHG induces a more severe decrease in the phosphorylation of Akt and GSK-3 $\beta$ than CHG in cultured HUVECs; this effect is associated with reduced cell viability [19]. In agreement with these data, it was demonstrated that IHG suppresses NO synthesis in cultured HUVECs to a greater extent than CHG via the inhibition of PI3K/Akt and eNOS activity [58]. The pro-apoptotic effect of IHG in cultured neuronal cells (PC12 cell line) also involves the PI3K/Akt pathway [133]. The oxidative and inflammatory stress and microglial activation induced by acute glucose fluctuation in the mouse microglial BV-2 cell line were mediated through the PI3K/Akt, NF- $\mathrm{KB}$ and MAPK cascades [134].

MAPK families play an important role in cell proliferation, differentiation and apoptosis. The MAPK families include extracellular signal-regulated kinase (ERK), JNK and p38 MAPK [180]. Some data point to the role of these signaling molecules in the realization of the effects of GV in the target organs. It was demonstrated that MAPK (ERK1/2), as well as the PI3K and NF- $\mathrm{KB}$ signaling pathways, is involved in the proliferative effect of IHG in VSMCs [138].

In vascular endothelial cells, IHG increased the phosphorylation of JNK [166]. The JNK pathway plays a central role in the cell response to hyperglycemia, oxidative stress, proinflammatory cytokines and other stress-inducing stimuli. The JNK-dependent effects include the regulation of gene expression, cell death and cellular senescence [181,182]. In patients with diabetes, JNK contributes to vascular insulin resistance and endothelial dysfunction [183]. It was demonstrated both in vivo and in vitro that the PKC/JNK pathway mediates the pro-apoptotic effect of glucose fluctuations in endothelial cells $[129,184]$. 
In diabetes, high glucose activates p38 MAPK signaling [181]; high GV may be an additional trigger of the event [166]. It was shown that GV generates the more severe up-regulation of type I collagen synthesis and fibrosis of aorta via the activation of the ROS/p38 MAPK/Runx2 pathway in Sprague Dawley rats with streptozotocin-induced diabetes [185]. In astroglial cells, glucose fluctuations induce toxicity with oxidative and inflammatory stress by activating p38 MAPK and NF- $\mathrm{KB}$ [99].

The interactions among the MAPK, NF- $\mathrm{kB}$ and TGF- $\beta /$ Smad signaling pathways are essential for fibrogenesis. It is well known that TGF- $\beta$ 's biological effects were realized by activating downstream mediators Smad 2 and Smad3, which is negatively regulated by an inhibitory Smad7 [186]. The activation of the MAPK/ERK and TGF- $\beta$ /Smad signaling pathways is considered as a cornerstone in the pathogenesis of renal fibrosis in diabetic kidney disease [187]. As it was demonstrated in mice with alloxan diabetes, excessive blood glucose fluctuations cause the more pronounced activation of the TGF- $\beta / \operatorname{Smad} 2$ and ERK/MAPK pathways in the kidney compared to stable hyperglycemia. These changes in signal transduction were accompanied by the marked increase in type I collagen synthesis and suppression of collagen degradation [188]. The inhibition of skin collagen synthesis and increase in collagen degradation under high GV is also attributed to both the MAPK and Smad signaling pathways [189].

AMPK is a master regulator of metabolism which acts as an intracellular sensor of energy availability [178]. The glucose shortage promotes AMPK activity; meanwhile, overnutrition inhibits it. In many cell types, AMPK stimulates glucose uptake via trafficking glucose transporters GLUT1 and GLUT4; acutely stimulates glycolysis; and, in the longer term, tends to promote oxidative metabolism. The activation of autophagic flux via ULK1 is considered as an important AMPK-dependent mechanism of cellular metabolic adaptation $[190,191]$. Recently, it has been demonstrated that high glucose represses AMPK signaling via MG53 E3 ubiquitin ligase-mediated AMPK $\alpha$ degradation and deactivation [192]. Currently, little is known about the effect of GV, which is characterized by intermittent glucose excess and deprivation, on AMPK activity in diabetes. It was found that the activation of AMPK by globular adiponectin can inhibit, at least partially, the IHG-induced apoptosis of HUVECs [193].

mTORC1 is another protein kinase that is regulated by glucose availability; however, unlike AMPK, mTORC1 is activated in high-glucose conditions. When it is activated, mTORC1 shifts the metabolic paradigm towards anabolic processes, promotes cell growth and suppresses autophagic flux [191]. It was demonstrated that the inhibition of AMPK by high glucose inversely correlates with the activation of the mechanistic target of rapamycin (mTOR) pathway in beta cells [194]. It is currently known that upon glucose depletion, mTORC1 is inhibited by AMPK-dependent and AMPK-independent mechanisms [195]. Recent data indicate that aldolase could be a sensor for both low and high glucose levels, linking to the AMPK and mTORC1 pathways [196]. In cancer, diabetes and other diseases characterized by abnormal glucose metabolism, mTORC1 is deregulated [195,197]. In diabetes, hyperactivated mTORC1 is involved in the pathogenesis of cardiomyopathy [198], diabetic retinopathy [199] and diabetic kidney disease [200]. Unfortunately, the role of mTORC1 signaling in GV-related vascular effects has not been studied to date.

Thus, the deteriorative effects of high GV in the target cells are realized through the PI3K/Akt, NF- $\mathrm{kB}$, MAPK (ERK), JNK, TGF- $\beta$ /Smad and other signaling pathways (Table 1). Elucidating the pathophysiological role of AMPK and mTORC1 under fluctuating glucose conditions is a promising challenge for future research. 
Table 1. The principal signaling pathways mediating the pathophysiological effects of high GV in diabetic complications.

\begin{tabular}{|c|c|c|}
\hline Effect & Pathways & Refs. \\
\hline Oxidative stress in endothelial and neural cells & PKC/NF-kB, PI3K/Akt, p38MAPK & {$[99,134,174,175]$} \\
\hline Endothelial dysfunction and apoptosis & PI3K/Akt, NF-kB, PKC/JNK & {$[19,58,129,176,184]$} \\
\hline Proliferation of VSMCs & MAPK (ERK1/2), PI3K/Akt, NF-kB & [138] \\
\hline Vascular low-grade inflammation & NF- $\kappa B$ and p38 MAPK & [162] \\
\hline Renal fibrosis & MAPK (ERK1/2) and TGF- $\beta /$ Smad & [188] \\
\hline Aortic fibrosis & TGF- $\beta /$ Smad, NF- $\kappa$ B, p38 MAPK and Runx2 & [185] \\
\hline Neuronal apoptosis and neurodegeneration & $\mathrm{PI} 3 \mathrm{~K} / \mathrm{Akt}, \mathrm{NF}-\mathrm{kB}$ & {$[133,134]$} \\
\hline
\end{tabular}

\section{Conclusions}

Current data indicate that the deteriorating effect of high GV on the targeted cells may be realized through a number of molecular abnormalities. Fluctuations in glucose levels alter the expression profile of a large number of genes and modulate the activity of intracellular signaling pathways. Epigenetic modifications prolong the effects of GV. These changes cause the dysfunction of cell organelles and disrupt the life cycle and synthetic function of endothelial cells and other cells of the vascular wall, the nervous system, the kidneys, the liver and other organs. These changes are manifested by biochemical and pathophysiological abnormalities underlying diabetic complications. The multiple deteriorative effects of GV provide further support for considering it as a therapeutic target in diabetes. Treatment modalities focused on reducing GV may have an advantage in diabetes management. Further study of the cellular and molecular effects of high GV is needed to develop targeted methods for the treatment and prevention of diabetic vascular and neural complications.

Author Contributions: Conceptualization and methodology, V.V.K.; writing-original draft preparation, V.V.K., A.I.K. and O.V.S.; writing-review and editing, V.V.K.; funding acquisition, V.V.K. All authors have read and agreed to the published version of the manuscript.

Funding: This research was funded by the Russian Science Foundation (grant № 20-15-00057).

Institutional Review Board Statement: The study was conducted according to the guidelines of the Declaration of Helsinki, and approved by the Ethics Committee of RICEL- Branch of IC\&G SB RAS (protocol N.158, date of approval: 1 June 2020).

Informed Consent Statement: Not applicable.

Data Availability Statement: The data presented in this study are available on request from the corresponding author.

Conflicts of Interest: The authors declare no conflict of interest. The funders had no role in the design of the study; in the collection, analyses or interpretation of data; in the writing of the manuscript, or in the decision to publish the results.
Abbreviations
AGEs Advanced glycation end-products
AMPK AMP-activated protein kinase
ATF4 Activating transcription factor 4
BMP Bone morphogenetic protein
CARM1 Coactivator-associated arginine methyltransferase 1
CGM Continuous glucose monitoring
$\mathrm{CHOP} \quad \mathrm{C} / \mathrm{EBP}$ homologous protein
CHG Constantly high glucose 


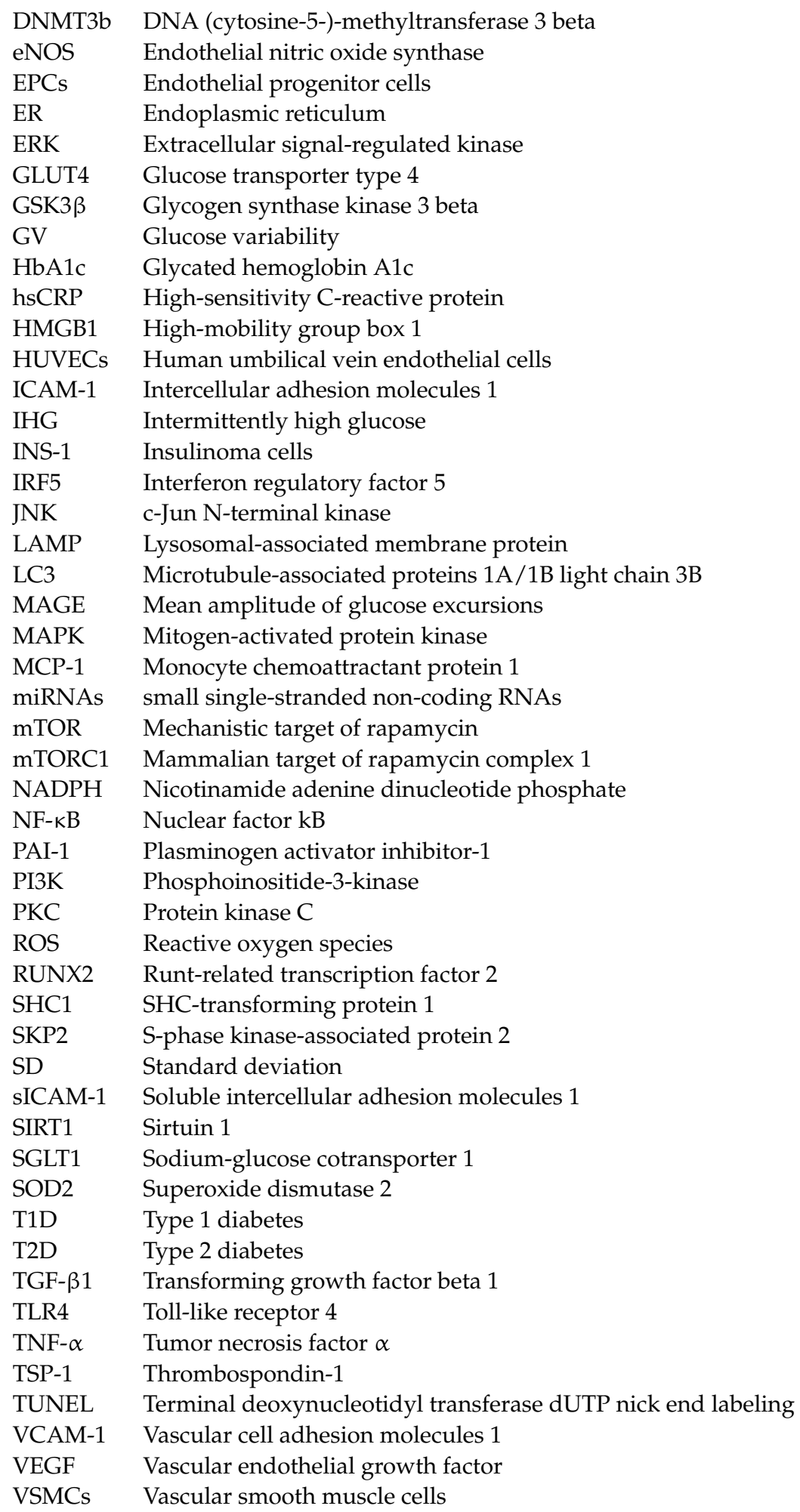

\section{References}

1. Rodbard, D. Glucose variability: A review of clinical applications and research developments. Diabetes Technol. Ther. 2018, 20, S25-S215. [CrossRef] [PubMed]

2. Umpierrez, G.E.; Kovatchev, B.P. Glycemic variability: How to measure and its clinical implication for type 2 diabetes. Am. J. Med. Sci. 2018, 356, 518-527. [CrossRef] [PubMed]

3. Danne, T.; Nimri, R.; Battelino, T.; Bergenstal, R.M.; Close, K.L.; De Vries, J.H.; Garg, S.; Heinemann, L.; Hirsch, I.; Amiel, S.A.; et al. International consensus on use of continuous glucose monitoring. Diabetes Care 2017, 40, 1631-1640. [CrossRef] [PubMed] 
4. Ceriello, A. Glucose variability and diabetic complications: Is it time to treat? Diabetes Care 2020, 43, 1169-1171. [CrossRef] [PubMed]

5. Zhou, Z.; Sun, B.; Huang, S.; Zhu, C.; Bian, M. Glycemic variability: Adverse clinical outcomes and how to improve it? Cardiovasc. Diabetol. 2020, 19, 102. [CrossRef] [PubMed]

6. Wadén, J.; Forsblom, C.; Thorn, L.M.; Gordin, D.; Saraheimo, M.; Groop, P.-H.; Finnish Diabetic Nephropathy Study Group. A1C variability predicts incident cardiovascular events, microalbuminuria, and overt diabetic nephropathy in patients with type 1 diabetes. Diabetes 2009, 58, 2649-2655. [CrossRef] [PubMed]

7. Luk, A.O.Y.; Ma, R.C.W.; Lau, E.S.H.; Yang, X.; Lau, W.W.Y.; Yu, L.W.L.; Chow, F.C.C.; Chan, J.C.N.; So, W.-Y. Risk Association of $\mathrm{HbA1c}$ variability with chronic kidney disease and cardiovascular disease in type 2 diabetes: Prospective analysis of the hong kong diabetes registry. Diabetes Metab. Res. Rev. 2013, 29, 384-390. [CrossRef]

8. Li, S.; Tang, X.; Luo, Y.; Wu, B.; Huang, Z.; Li, Z.; Peng, L.; Ling, Y.; Zhu, J.; Zhong, J.; et al. Impact of long-term glucose variability on coronary atherosclerosis progression in patients with type 2 diabetes: A 2.3 year follow-up study. Cardiovasc. Diabetol. 2020, 19, 146. [CrossRef] [PubMed]

9. Hirakawa, Y.; Arima, H.; Zoungas, S.; Ninomiya, T.; Cooper, M.; Hamet, P.; Mancia, G.; Poulter, N.; Harrap, S.; Woodward, M.; et al. Impact of visit-to-visit glycemic variability on the risks of macrovascular and microvascular events and all-cause mortality in type 2 diabetes: The ADVANCE trial. Diabetes Care 2014, 37, 2359-2365. [CrossRef] [PubMed]

10. Zinman, B.; Marso, S.P.; Poulter, N.R.; Emerson, S.S.; Pieber, T.R.; Pratley, R.E.; Lange, M.; Brown-Frandsen, K.; Moses, A.; Ocampo Francisco, A.M.; et al. Day-to-day fasting glycaemic variability in DEVOTE: Associations with severe hypoglycaemia and cardiovascular outcomes (DEVOTE 2). Diabetologia 2018, 61, 48-57. [CrossRef]

11. Zhou, J.J.; Schwenke, D.C.; Bahn, G.; Reaven, P.; VADT Investigators. Glycemic variation and cardiovascular risk in the veterans affairs diabetes trial. Diabetes Care 2018, 41, 2187-2194. [CrossRef]

12. Kaze, A.D.; Santhanam, P.; Erqou, S.; Ahima, R.S.; Echouffo-Tcheugui, J.B. Long-term variability of glycemic markers and risk of all-cause mortality in type 2 diabetes: The look AHEAD study. BMJ Open Diabetes Res. Care 2020, 8. [CrossRef] [PubMed]

13. Ge, Q.M.; Dong, Y.; Zhang, H.M.; Su, Q. Effects of intermittent high glucose on oxidative stress in endothelial cells. Acta Diabetol. 2010, 47 (Suppl. S1), 97-103. [CrossRef]

14. Sun, L.-Q.; Xue, B.; Li, X.-J.; Wang, X.; Qu, L.; Zhang, T.-T.; Zhao, J.; Wang, B.-A.; Zou, X.-M.; Mu, Y.-M.; et al. Inhibitory effects of salvianolic acid b on apoptosis of schwann cells and its mechanism induced by intermittent high glucose. Life Sci. 2012, 90, 99-108. [CrossRef]

15. Sun, L.-Q.; Chen, Y.-Y.; Wang, X.; Li, X.-J.; Xue, B.; Qu, L.; Zhang, T.-T.; Mu, Y.-M.; Lu, J.-M. The protective effect of alpha lipoic acid on schwann cells exposed to constant or intermittent high glucose. Biochem. Pharmacol. 2012, 84, 961-973. [CrossRef] [PubMed]

16. Sun, J.; Xu, Y.; Deng, H.; Sun, S.; Dai, Z.; Sun, Y. Intermittent high glucose exacerbates the aberrant production of adiponectin and resistin through mitochondrial superoxide overproduction in adipocytes. J. Mol. Endocrinol. 2010, 44, 179-185. [CrossRef]

17. Zhang, Z.; Li, J.; Yang, L.; Chen, R.; Yang, R.; Zhang, H.; Cai, D.; Chen, H. The cytotoxic role of intermittent high glucose on apoptosis and cell viability in pancreatic beta cells. J. Diabetes Res. 2014, 2014, 712781. [CrossRef] [PubMed]

18. Zhang, X.-G.; Zhang, Y.-Q.; Zhao, D.-K.; Wu, J.-X.; Zhao, J.; Jiao, X.-M.; Chen, B.; Lv, X.-F. Relationship between blood glucose fluctuation and macrovascular endothelial dysfunction in type 2 diabetic patients with coronary heart disease. Eur. Rev. Med. Pharmacol. Sci. 2014, 18, 3593-3600.

19. Wang, J.; Yin, H.; Huang, Y.; Guo, C.; Xia, C.; Liu, Q.; Zhang, L. Panax quinquefolius saponin of stem and leaf attenuates intermittent high glucose-induced oxidative stress injury in cultured human umbilical vein endothelial cells via PI3K/Akt/GSK-3 $\beta$ Pathway. Evid. Based Complement. Altern. Med. 2013, 2013, 196283. [CrossRef]

20. He, Y.-T.; Xing, S.-S.; Gao, L.; Wang, J.; Xing, Q.-C.; Zhang, W. Ginkgo biloba attenuates oxidative DNA damage of human umbilical vein endothelial cells induced by intermittent high glucose. Pharmazie 2014, 69, 203-207.

21. Sun, J.; Xu, Y.; Sun, S.; Sun, Y.; Wang, X. Intermittent high glucose enhances cell proliferation and VEGF expression in retinal endothelial cells: The role of mitochondrial reactive oxygen species. Mol. Cell. Biochem. 2010, 343, 27-35. [CrossRef]

22. Hu, Z.; Fang, W.; Liu, Y.; Liang, H.; Chen, W.; Wang, H. Acute glucose fluctuation promotes RAGE expression via reactive oxygen species-mediated NF-kB activation in rat podocytes. Mol. Med. Rep. 2021, 23, 1-9. [CrossRef]

23. Sun, J.; Xu, Y.; Dai, Z.; Sun, Y. Intermittent high glucose stimulate MCP-1, IL-18, and PAI-1, but inhibit adiponectin expression and secretion in adipocytes dependent of ROS. Cell Biochem. Biophys. 2009, 55, 173-180. [CrossRef] [PubMed]

24. Hou, Z.-Q.; Li, H.-L.; Gao, L.; Pan, L.; Zhao, J.-J.; Li, G.-W. Involvement of chronic stresses in rat islet and INS-1 cell glucotoxicity induced by intermittent high glucose. Mol. Cell. Endocrinol. 2008, 291,71-78. [CrossRef] [PubMed]

25. Wu, N.; Shen, H.; Liu, H.; Wang, Y.; Bai, Y.; Han, P. Acute blood glucose fluctuation enhances rat aorta endothelial cell apoptosis, oxidative stress and pro-inflammatory cytokine expression in vivo. Cardiovasc. Diabetol. 2016, 15, 109. [CrossRef] [PubMed]

26. Chang, C.-M.; Hsieh, C.-J.; Huang, J.-C.; Huang, I.-C. Acute and chronic fluctuations in blood glucose levels can increase oxidative stress in type 2 diabetes mellitus. Acta Diabetol. 2012, 49 (Suppl. S1), S171-S177. [CrossRef]

27. Wentholt, I.M.E.; Kulik, W.; Michels, R.P.J.; Hoekstra, J.B.L.; De Vries, J.H. Glucose fluctuations and activation of oxidative stress in patients with type 1 diabetes. Diabetologia 2008, 51, 183-190. [CrossRef]

28. Siegelaar, S.E.; Barwari, T.; Kulik, W.; Hoekstra, J.B.; De Vries, J.H. No relevant relationship between glucose variability and oxidative stress in well-regulated type 2 diabetes patients. J. Diabetes Sci. Technol. 2011, 5, 86-92. [CrossRef] 
29. Kohata, Y.; Ohara, M.; Nagaike, H.; Fujikawa, T.; Osaka, N.; Goto, S.; Fukase, A.; Kushima, H.; Hiromura, M.; Terasaki, M.; et al. Association of hemoglobin A1c, 1,5-Anhydro-D-Glucitol and glycated albumin with oxidative stress in type 2 diabetes mellitus patients: A cross-sectional study. Diabetes Ther. 2020, 11, 655-665. [CrossRef]

30. Klimontov, V.V.; Myakina, N.E. Glucose variability indices predict the episodes of nocturnal hypoglycemia in elderly type 2 diabetic patients treated with insulin. Diabetes Metab. Syndr. 2017, 11, 119-124. [CrossRef]

31. Gómez, A.M.; Henao, D.C.; Imitola-Madero, A.; Taboada, L.B.; Cruz, V.; Robledo Gómez, M.A.; Rondón, M.; Muñoz-Velandia, O.; García-Jaramillo, M.; León Vargas, F.M. Defining high glycemic variability in type 1 diabetes: Comparison of multiple indexes to identify patients at risk of hypoglycemia. Diabetes Technol. Ther. 2019, 21, 430-439. [CrossRef]

32. Ceriello, A.; Novials, A.; Ortega, E.; La Sala, L.; Pujadas, G.; Testa, R.; Bonfigli, A.R.; Esposito, K.; Giugliano, D. Evidence that hyperglycemia after recovery from hypoglycemia worsens endothelial function and increases oxidative stress and inflammation in healthy control subjects and subjects with type 1 diabetes. Diabetes 2012, 61, 2993-2997. [CrossRef]

33. Ceriello, A.; Novials, A.; Ortega, E.; Pujadas, G.; La Sala, L.; Testa, R.; Bonfigli, A.R.; Genovese, S. Hyperglycemia following recovery from hypoglycemia worsens endothelial damage and thrombosis activation in type 1 diabetes and in healthy controls Nutr. Metab. Cardiovasc. Dis. 2014, 24, 116-123. [CrossRef]

34. Fishman, S.L.; Sonmez, H.; Basman, C.; Singh, V.; Poretsky, L. The role of advanced glycation end-products in the development of coronary artery disease in patients with and without diabetes mellitus: A review. Mol. Med. 2018, 24, 59. [CrossRef] [PubMed]

35. Testa, R.; Bonfigli, A.R.; Prattichizzo, F.; La Sala, L.; De Nigris, V.; Ceriello, A. The "Metabolic Memory" theory and the early treatment of hyperglycemia in prevention of diabetic complications. Nutrients 2017, 9, 437. [CrossRef] [PubMed]

36. Yamagishi, S.-I.; Nakamura, N.; Matsui, T. Glycation and cardiovascular disease in diabetes: A perspective on the concept of metabolic memory. J. Diabetes 2017, 9, 141-148. [CrossRef]

37. Schisano, B.; Tripathi, G.; McGee, K.; McTernan, P.G.; Ceriello, A. Glucose oscillations, more than constant high glucose, induce P53 activation and a metabolic memory in human endothelial cells. Diabetologia 2011, 54, 1219-1226. [CrossRef]

38. Corgnali, M.; Piconi, L.; Ihnat, M.; Ceriello, A. Evaluation of gliclazide ability to attenuate the hyperglycaemic "memory" induced by high glucose in isolated human endothelial cells. Diabetes Metab. Res. Rev. 2008, 24, 301-309. [CrossRef] [PubMed]

39. Domingueti, C.P.; Dusse, L.M.S.; das Carvalho, M.G.; de Sousa, L.P.; Gomes, K.B.; Fernandes, A.P. Diabetes mellitus: The linkage between oxidative stress, inflammation, hypercoagulability and vascular complications. J. Diabetes Complicat. 2016, 30, 738-745. [CrossRef]

40. Nguyen, D.V.; Shaw, L.C.; Grant, M.B. Inflammation in the pathogenesis of microvascular complications in diabetes. Front. Endocrinol. 2012, 3, 170. [CrossRef]

41. Piconi, L.; Quagliaro, L.; Assaloni, R.; Da Ros, R.; Maier, A.; Zuodar, G.; Ceriello, A. Constant and intermittent high glucose enhances endothelial cell apoptosis through mitochondrial superoxide overproduction. Diabetes Metab. Res. Rev. 2006, 22, 198-203. [CrossRef] [PubMed]

42. Quagliaro, L.; Piconi, L.; Assaloni, R.; Da Ros, R.; Maier, A.; Zuodar, G.; Ceriello, A. Intermittent high glucose enhances ICAM-1, VCAM-1 and e-selectin expression in human umbilical vein endothelial cells in culture: The distinct role of protein kinase $C$ and mitochondrial superoxide production. Atherosclerosis 2005, 183, 259-267. [CrossRef] [PubMed]

43. Li-Bo, Y.; Wen-Bo, Q.; Xiao-Hong, L.; You-Lun, F.; Tie, Z. Intermittent high glucose promotes expression of proinflammatory cytokines in monocytes. Inflamm. Res. 2011, 60, 367-370. [CrossRef] [PubMed]

44. Zhang, C.; Bi, Y.; Jin, G.; Gan, H.; Yu, L. High and fluctuating glucose levels increase the expression and secretion of interleukin-18 in mouse peritoneal macrophages. Mol. Med. Rep. 2015, 12, 2715-2720. [CrossRef] [PubMed]

45. Al-Rashed, F.; Sindhu, S.; Arefanian, H.; Al Madhoun, A.; Kochumon, S.; Thomas, R.; Al-Kandari, S.; Alghaith, A.; Jacob, T.; Al-Mulla, F.; et al. Repetitive intermittent hyperglycemia drives the $\mathrm{m} 1$ polarization and inflammatory responses in THP-1 macrophages through the mechanism involving the TLR4-IRF5 pathway. Cells 2020, 9, 1892. [CrossRef] [PubMed]

46. Ratter, J.M.; Rooijackers, H.M.M.; Tack, C.J.; Hijmans, A.G.M.; Netea, M.G.; de Galan, B.E.; Stienstra, R. Proinflammatory effects of hypoglycemia in humans with or without diabetes. Diabetes 2017, 66, 1052-1061. [CrossRef] [PubMed]

47. Ratter, J.M.; Rooijackers, H.M.M.; Jacobs, C.W.M.; de Galan, B.E.; Tack, C.J.; Stienstra, R. Hypoglycaemia induces recruitment of non-classical monocytes and cytotoxic lymphocyte subsets in type 1 diabetes. Diabetologia 2018, 61, 2069-2071. [CrossRef]

48. Ceriello, A.; Novials, A.; Ortega, E.; Canivell, S.; La Sala, L.; Pujadas, G.; Esposito, K.; Giugliano, D.; Genovese, S. Glucagon-like peptide 1 reduces endothelial dysfunction, inflammation, and oxidative stress induced by both hyperglycemia and hypoglycemia in type 1 diabetes. Diabetes Care 2013, 36, 2346-2350. [CrossRef]

49. Ceriello, A.; Novials, A.; Ortega, E.; Canivell, S.; Pujadas, G.; La Sala, L.; Bucciarelli, L.; Rondinelli, M.; Genovese, S. Vitamin C further improves the protective effect of GLP-1 on the ischemia-reperfusion-like effect induced by hyperglycemia posthypoglycemia in type 1 diabetes. Cardiovasc. Diabetol. 2013, 12, 97. [CrossRef]

50. Kiec-Wilk, B.; Matejko, B.; Razny, U.; Stankiewicz, M.; Skupien, J.; Klupa, T.; Malecki, M.T. Hypoglycemic episodes are associated with inflammatory status in patients with type 1 diabetes mellitus. Atherosclerosis 2016, 251, 334-338. [CrossRef]

51. Cherney, D.Z.I.; Scholey, J.W.; Sochett, E.; Bradley, T.J.; Reich, H.N. The acute effect of clamped hyperglycemia on the urinary excretion of inflammatory cytokines/chemokines in uncomplicated type 1 diabetes: A pilot study. Diabetes Care 2011, 34, 177-180. [CrossRef] [PubMed] 
52. Eik, W.; Marcon, S.S.; Krupek, T.; Previdelli, I.T.S.; Pereira, O.C.N.; Silva, M.a.R.C.P.; Bazotte, R.B. Blood levels of pro-inflammatory and anti-inflammatory cytokines during an oral glucose tolerance test in patients with symptoms suggesting reactive hypoglycemia. Braz. J. Med. Biol. Res. 2016, 49. [CrossRef]

53. Drummond, J.B.; Barbosa, I.G.; Dantzer, R.; Teixeira, A.L. The effect of insulin-induced hypoglycemia on inflammatory markers: A systematic review. Brain Behav. Immun. 2018, 73, 41-50. [CrossRef] [PubMed]

54. Kaya, A.; Koçyiğit, C.; Çatlı, G.; Özkan, E.B.; Dündar, B.N. The relationship between glycemic variability and inflammatory markers in obese children with insulin resistance and metabolic syndrome. J. Clin. Res. Pediatr. Endocrinol. 2017, 9, $202-207$. [CrossRef] [PubMed]

55. Klimontov, V.V.; Tyan, N.V.; Fazullina, O.N.; Myakina, N.E.; Orlov, N.B.; Konenkov, V.I. Acute-phase serum proteins and adipocytokines in women with type 2 diabetes mellitus: Relationships with body composition and blood glucose fluctuations. Ter. Arkh. 2016, 88, 35-41. [CrossRef] [PubMed]

56. Buscemi, S.; Verga, S.; Cottone, S.; Azzolina, V.; Buscemi, B.; Gioia, D.; Cerasola, G. Glycaemic variability and inflammation in subjects with metabolic syndrome. Acta Diabetol. 2009, 46, 55-61. [CrossRef] [PubMed]

57. Paul, S.; Ali, A.; Katare, R. Molecular complexities underlying the vascular complications of diabetes mellitus-A comprehensive review. J. Diabetes Complicat. 2020, 34, 107613. [CrossRef]

58. Liao, J.; Lei, M.; Chen, X.; Liu, F. Effect of intermittent high glucose on synthesis of nitric oxide in human umbilical vein endothelial cells and its mechanism. Zhong Nan Da Xue Xue Bao. Yi Xue Ban 2010, 35, 295-300. [CrossRef]

59. Kuricová, K.; Pácal, L.; Šoupal, J.; Prázný, M.; Kaňková, K. Effect of glucose variability on pathways associated with glucotoxicity in diabetes: Evaluation of a novel in vitro experimental approach. Diabetes Res. Clin. Pract. 2016, 114, 1-8. [CrossRef]

60. Maeda, M.; Hayashi, T.; Mizuno, N.; Hattori, Y.; Kuzuya, M. Intermittent high glucose implements stress-induced senescence in human vascular endothelial cells: Role of superoxide production by NADPH oxidase. PLoS ONE 2015, 10, e0123169. [CrossRef]

61. Horváth, E.M.; Benko, R.; Kiss, L.; Murányi, M.; Pék, T.; Fekete, K.; Bárány, T.; Somlai, A.; Csordás, A.; Szabo, C. Rapid “glycaemic Swings" induce nitrosative stress, activate Poly(ADP-Ribose) polymerase and impair endothelial function in a rat model of diabetes mellitus. Diabetologia 2009, 52, 952-961. [CrossRef]

62. Di Flaviani, A.; Picconi, F.; Di Stefano, P.; Giordani, I.; Malandrucco, I.; Maggio, P.; Palazzo, P.; Sgreccia, F.; Peraldo, C.; Farina, F.; et al. Impact of glycemic and blood pressure variability on surrogate measures of cardiovascular outcomes in type 2 diabetic patients. Diabetes Care 2011, 34, 1605-1609. [CrossRef]

63. Peña, A.S.; Couper, J.J.; Harrington, J.; Gent, R.; Fairchild, J.; Tham, E.; Baghurst, P. Hypoglycemia, but not glucose variability, relates to vascular function in children with type 1 diabetes. Diabetes Technol. Ther. 2012, 14, 457-462. [CrossRef] [PubMed]

64. Al-Qaissi, A.; Papageorgiou, M.; Deshmukh, H.; Madden, L.A.; Rigby, A.; Kilpatrick, E.S.; Atkin, S.L.; Sathyapalan, T. Effects of acute insulin-induced hypoglycaemia on endothelial microparticles in adults with and without type 2 diabetes. Diabetes Obes. Metab. 2019, 21, 533-540. [CrossRef] [PubMed]

65. Tiftikcioglu, B.I.; Bilgin, S.; Duksal, T.; Kose, S.; Zorlu, Y. Autonomic neuropathy and endothelial dysfunction in patients with impaired glucose tolerance or type 2 diabetes mellitus. Medicine 2016, 95, e3340. [CrossRef]

66. Foreman, Y.D.; Brouwers, M.C.G.J.; Berendschot, T.T.J.M.; van Dongen, M.C.J.M.; Eussen, S.J.P.M.; van Greevenbroek, M.M.J.; Henry, R.M.A.; Houben, A.J.H.M.; van der Kallen, C.J.H.; Kroon, A.A.; et al. The oral glucose tolerance test-derived incremental glucose peak is associated with greater arterial stiffness and maladaptive arterial remodeling: The Maastricht study. Cardiovasc. Diabetol. 2019, 18, 152. [CrossRef]

67. Zhang, L.; Sun, H.; Liu, S.; Gao, J.; Xia, J. Glycemic variability is associated with vascular calcification by the markers of endoplasmic reticulum stress-related apoptosis, Wnt1, Galectin-3 and BMP-2. Diabetol. Metab. Syndr. 2019, 11, 67. [CrossRef]

68. Suslova, T.E.; Sitozhevskii, A.V.; Ogurkova, O.N.; Kravchenko, E.S.; Kologrivova, I.V.; Anfinogenova, Y.; Karpov, R.S. Platelet hemostasis in patients with metabolic syndrome and type 2 diabetes mellitus: CGMP- and NO-dependent mechanisms in the insulin-mediated platelet aggregation. Front. Physiol. 2014, 5, 501. [CrossRef] [PubMed]

69. Santilli, F.; Formoso, G.; Sbraccia, P.; Averna, M.; Miccoli, R.; Di Fulvio, P.; Ganci, A.; Pulizzi, N.; Lattanzio, S.; Ciabattoni, G.; et al. Postprandial hyperglycemia is a determinant of platelet activation in early type 2 diabetes mellitus. J. Thromb. Haemost. 2010, 8 , 828-837. [CrossRef]

70. Nusca, A.; Tuccinardi, D.; Proscia, C.; Melfi, R.; Manfrini, S.; Nicolucci, A.; Ceriello, A.; Pozzilli, P.; Ussia, G.P.; Grigioni, F.; et al. Incremental role of glycaemic variability over $\mathrm{HbA} 1 \mathrm{c}$ in identifying type 2 diabetic patients with high platelet reactivity undergoing percutaneous coronary intervention. Cardiovasc. Diabetol. 2019, 18, 147. [CrossRef] [PubMed]

71. Gu, G.; Chen, L.; Wang, M.; Cui, W. Acute fluctuation in blood glucose has no effect on platelet aggregation rate. Clin. Lab. 2014, 60, 1071-1073. [CrossRef] [PubMed]

72. Iqbal, A.; Prince, L.R.; Novodvorsky, P.; Bernjak, A.; Thomas, M.R.; Birch, L.; Lambert, D.; Kay, L.J.; Wright, F.J.; Macdonald, I.A.; et al. Effect of hypoglycemia on inflammatory responses and the response to low-dose endotoxemia in humans. J. Clin. Endocrinol. Metab. 2019, 104, 1187-1199. [CrossRef] [PubMed]

73. Costa, P.Z.; Soares, R. Neovascularization in diabetes and its complications. Unraveling the angiogenic paradox. Life Sci. 2013, 92, 1037-1045. [CrossRef] [PubMed]

74. Guo, J.; Sang, Y.; Yin, T.; Wang, B.; Yang, W.; Li, X.; Li, H.; Kang, Y. MiR-1273g-3p participates in acute glucose fluctuation-induced autophagy, dysfunction, and proliferation attenuation in human umbilical vein endothelial cells. Am. J. Physiol. Endocrinol. Metab. 2016, 310, E734-E743. [CrossRef] [PubMed] 
75. Biscetti, F.; Pitocco, D.; Straface, G.; Zaccardi, F.; de Cristofaro, R.; Rizzo, P.; Lancellotti, S.; Arena, V.; Stigliano, E.; Musella, T.; et al. Glycaemic variability affects ischaemia-induced angiogenesis in diabetic mice. Clin. Sci. 2011, 121, 555-564. [CrossRef]

76. Hu, L.; Dai, S.-C.; Luan, X.; Chen, J.; Cannavicci, A. Dysfunction and therapeutic potential of endothelial progenitor cells in diabetes mellitus. J. Clin. Med. Res. 2018, 10, 752-757. [CrossRef] [PubMed]

77. Inaba, Y.; Tsutsumi, C.; Haseda, F.; Fujisawa, R.; Mitsui, S.; Sano, H.; Terasaki, J.; Hanafusa, T.; Imagawa, A. Impact of glycemic variability on the levels of endothelial progenitor cells in patients with type 1 diabetes. Diabetol. Int. 2018, 9, 113-120. [CrossRef]

78. Maiorino, M.I.; Casciano, O.; Della Volpe, E.; Bellastella, G.; Giugliano, D.; Esposito, K. Reducing glucose variability with continuous subcutaneous insulin infusion increases endothelial progenitor cells in type 1 diabetes: An observational study. Endocrine 2016, 52, 244-252. [CrossRef]

79. Boscari, F.; D’Anna, M.; Bonora, B.M.; Tresso, S.; Cappellari, R.; Avogaro, A.; Bruttomesso, D.; Fadini, G.P. Effects of glucose variability on hematopoietic stem/progenitor cells in patients with type 1 diabetes. J. Endocrinol. Invest. 2021, 44, 119-126. [CrossRef]

80. Goth, A.; Lengyel, L.; Nadasdi, N.; Savely, C. Renal lesions due to fluctuations in blood sugar levels. Acta Med. Scand. 1957, 158, 475-480. [CrossRef]

81. Takeuchi, A.; Throckmorton, D.C.; Brogden, A.P.; Yoshizawa, N.; Rasmussen, H.; Kashgarian, M. Periodic high extracellular glucose enhances production of collagens iii and iv by mesangial cells. Am. J. Physiol. 1995, 268, F13-F19. [CrossRef] [PubMed]

82. Jones, S.C.; Saunders, H.J.; Qi, W.; Pollock, C.A. Intermittent high glucose enhances cell growth and collagen synthesis in cultured human tubulointerstitial cells. Diabetologia 1999, 42, 1113-1119. [CrossRef] [PubMed]

83. Polhill, T.S.; Saad, S.; Poronnik, P.; Fulcher, G.R.; Pollock, C.A. Short-term peaks in glucose promote renal fibrogenesis independently of total glucose exposure. Am. J. Physiol. Renal. Physiol. 2004, 287, F268-F273. [CrossRef] [PubMed]

84. Ying, C.; Zhou, X.; Chang, Z.; Ling, H.; Cheng, X.; Li, W. Blood glucose fluctuation accelerates renal injury involved to inhibit the akt signaling pathway in diabetic rats. Endocrine 2016, 53, 81-96. [CrossRef] [PubMed]

85. Yang, Y.-F.; Li, T.-C.; Li, C.-I.; Liu, C.-S.; Lin, W.-Y.; Yang, S.-Y.; Chiang, J.-H.; Huang, C.-C.; Sung, F.-C.; Lin, C.-C. Visit-to-visit glucose variability predicts the development of end-stage renal disease in type 2 diabetes: 10-year follow-up of Taiwan diabetes study. Medicine 2015, 94, e1804. [CrossRef]

86. Takenouchi, A.; Tsuboi, A.; Terazawa-Watanabe, M.; Kurata, M.; Fukuo, K.; Kazumi, T. Direct association of visit-to-visit HbA1c variation with annual decline in estimated glomerular filtration rate in patients with type 2 diabetes. J. Diabetes Metab. Disord. 2015, 14, 69. [CrossRef] [PubMed]

87. Gibb, F.W.; McKnight, J.A.; Clarke, C.; Strachan, M.W.J. Preserved C-peptide secretion is associated with fewer low-glucose events and lower glucose variability on flash glucose monitoring in adults with type 1 diabetes. Diabetologia 2020, 63, 906-914. [CrossRef]

88. Christensen, M.B.; Gæde, P.; Hommel, E.; Gotfredsen, A.; Nørgaard, K. Glycaemic variability and hypoglycaemia are associated with c-peptide levels in insulin-treated type 2 diabetes. Diabetes Metab. 2020, 46, 61-65. [CrossRef]

89. Zhang, Y.; Dai, J.; Han, X.; Zhao, Y.; Zhang, H.; Liu, X.; Li, W.; Ling, H.; Zhou, X.; Ying, C. Glycemic variability indices determined by self-monitoring of blood glucose are associated with $\beta$-cell function in chinese patients with type 2 diabetes. Diabetes Res. Clin. Pract. 2020, 164, 108152. [CrossRef]

90. Cheong, Y.-H.; Kim, M.-K.; Son, M.-H.; Kaang, B.-K. Glucose Exposure pattern determines glucagon-like peptide 1 receptor expression and signaling through endoplasmic reticulum stress in rat insulinoma cells. Biochem. Biophys. Res. Commun. 2011, 414, 220-225. [CrossRef]

91. Shao, C.; Gu, J.; Meng, X.; Zheng, H.; Wang, D. Systematic Investigation into the role of intermittent high glucose in pancreatic beta-cells. Int. J. Clin. Exp. Med. 2015, 8, 5462-5469.

92. Wada, J.; Nakatsuka, A. Mitochondrial dynamics and mitochondrial dysfunction in diabetes. Acta Med. Okayama 2016, 70, 151-158. [CrossRef]

93. Galvan, D.L.; Green, N.H.; Danesh, F.R. The hallmarks of mitochondrial dysfunction in chronic kidney disease. Kidney Int. 2017, 92, 1051-1057. [CrossRef] [PubMed]

94. Wu, M.-Y.; Yiang, G.-T.; Lai, T.-T.; Li, C.-J. The oxidative stress and mitochondrial dysfunction during the pathogenesis of diabetic retinopathy. Oxid. Med. Cell. Longev. 2018, 2018, 3420187. [CrossRef] [PubMed]

95. Cieluch, A.; Uruska, A.; Zozulinska-Ziolkiewicz, D. Can we prevent mitochondrial dysfunction and diabetic cardiomyopathy in type 1 diabetes mellitus? Pathophysiology and treatment options. Int. J. Mol. Sci. 2020, 21, 2852. [CrossRef] [PubMed]

96. Rocha, M.; Diaz-Morales, N.; Rovira-Llopis, S.; Escribano-Lopez, I.; Bañuls, C.; Hernandez-Mijares, A.; Diamanti-Kandarakis, E.; Victor, V.M. Mitochondrial dysfunction and endoplasmic reticulum stress in diabetes. Curr. Pharm. Des. 2016, 22, 2640-2649. [CrossRef]

97. La Sala, L.; Mrakic-Sposta, S.; Micheloni, S.; Prattichizzo, F.; Ceriello, A. Glucose-sensing MicroRNA-21 disrupts ROS homeostasis and impairs antioxidant responses in cellular glucose variability. Cardiovasc. Diabetol. 2018, 17, 105. [CrossRef]

98. Tao, S.; Ren, Y.; Zheng, H.; Zhao, M.; Zhang, X.; Zhu, Y.; Yang, J.; Zheng, S. Salvianolic acid B inhibits intermittent high glucoseinduced INS-1 cell apoptosis through regulation of Bcl-2 proteins and mitochondrial membrane potential. Eur. J. Pharmacol. 2017, 814, 56-62. [CrossRef] 
99. Quincozes-Santos, A.; Bobermin, L.D.; de Assis, A.M.; Gonçalves, C.-A.; Souza, D.O. Fluctuations in glucose levels induce glial toxicity with glutamatergic, oxidative and inflammatory implications. Biochim. Biophys. Acta Mol. Basis Dis. 2017, 1863, 1-14. [CrossRef]

100. Yin, X.; Zheng, F.; Pan, Q.; Zhang, S.; Yu, D.; Xu, Z.; Li, H. Glucose fluctuation increased hepatocyte apoptosis under lipotoxicity and the involvement of mitochondrial permeability transition opening. J. Mol. Endocrinol. 2015, 55, 169-181. [CrossRef]

101. Saito, S.; Thuc, L.C.; Teshima, Y.; Nakada, C.; Nishio, S.; Kondo, H.; Fukui, A.; Abe, I.; Ebata, Y.; Saikawa, T.; et al. Glucose fluctuations aggravate cardiac susceptibility to ischemia/reperfusion injury by modulating MicroRNAs expression. Circ. J. 2016, 80, 186-195. [CrossRef]

102. Chareyron, I.; Christen, S.; Moco, S.; Valsesia, A.; Lassueur, S.; Dayon, L.; Wollheim, C.B.; Santo Domingo, J.; Wiederkehr, A. Augmented mitochondrial energy metabolism is an early response to chronic glucose stress in human pancreatic beta cells. Diabetologia 2020, 63, 2628-2640. [CrossRef]

103. Xu, W.-L.; Liu, S.; Li, N.; Ye, L.-F.; Zha, M.; Li, C.-Y.; Zhao, Y.; Pu, Q.; Bao, J.-J.; Chen, X.-J.; et al. Quercetin antagonizes glucose fluctuation induced renal injury by inhibiting aerobic glycolysis via HIF-1 $\alpha /$ MiR-210/ISCU/FeS pathway. Front. Med. 2021, 8, 656086. [CrossRef]

104. Silva-Rodrigues, T.; de-Souza-Ferreira, E.; Machado, C.M.; Cabral-Braga, B.; Rodrigues-Ferreira, C.; Galina, A. Hyperglycemia in a type 1 diabetes mellitus model causes a shift in mitochondria coupled-glucose phosphorylation and redox metabolism in rat brain. Free Radic. Biol. Med. 2020, 160, 796-806. [CrossRef] [PubMed]

105. Lemmer, I.L.; Willemsen, N.; Hilal, N.; Bartelt, A. A Guide to understanding endoplasmic reticulum stress in metabolic disorders. Mol. Metab. 2021, 47, 101169. [CrossRef] [PubMed]

106. Sankrityayan, H.; Oza, M.J.; Kulkarni, Y.A.; Mulay, S.R.; Gaikwad, A.B. ER stress response mediates diabetic microvascular complications. Drug Discov. Today 2019, 24, 2247-2257. [CrossRef] [PubMed]

107. Zhong, Y.; Wang, J.J.; Zhang, S.X. Intermittent but not constant high glucose induces ER stress and inflammation in human retinal pericytes. Adv. Exp. Med. Biol. 2012, 723, 285-292. [CrossRef] [PubMed]

108. Ikesugi, K.; Mulhern, M.L.; Madson, C.J.; Hosoya, K.-I.; Terasaki, T.; Kador, P.F.; Shinohara, T. Induction of endoplasmic reticulum stress in retinal pericytes by glucose deprivation. Curr. Eye Res. 2006, 31, 947-953. [CrossRef] [PubMed]

109. Kato, A.; Tatsumi, Y.; Yako, H.; Sango, K.; Himeno, T.; Kondo, M.; Kato, Y.; Kamiya, H.; Nakamura, J.; Kato, K. Recurrent short-term hypoglycemia and hyperglycemia induce apoptosis and oxidative stress via the ER stress response in immortalized adult mouse schwann (IMS32) cells. Neurosci. Res. 2019, 147, 26-32. [CrossRef]

110. Sage, A.T.; Holtby-Ottenhof, S.; Shi, Y.; Damjanovic, S.; Sharma, A.M.; Werstuck, G.H. Metabolic syndrome and acute hyperglycemia are associated with endoplasmic reticulum stress in human mononuclear cells. Obesity 2012, 20, 748-755. [CrossRef]

111. Ichimiya, T.; Yamakawa, T.; Hirano, T.; Yokoyama, Y.; Hayashi, Y.; Hirayama, D.; Wagatsuma, K.; Itoi, T.; Nakase, H. Autophagy and autophagy-related diseases: A review. Int. J. Mol. Sci. 2020, 21, 8974. [CrossRef]

112. Mizushima, N.; Levine, B. Autophagy in human diseases. N. Engl. J. Med. 2020, 383, 1564-1576. [CrossRef]

113. Marasco, M.R.; Linnemann, A.K. $\beta$-cell autophagy in diabetes pathogenesis. Endocrinology 2018, 159, 2127-2141. [CrossRef] [PubMed]

114. Muralidharan, C.; Conteh, A.M.; Marasco, M.R.; Crowder, J.J.; Kuipers, J.; de Boer, P.; Linnemann, A.K. Pancreatic beta cell autophagy is impaired in type 1 diabetes. Diabetologia 2021, 64, 865-877. [CrossRef] [PubMed]

115. Tao, T.; Xu, H. Autophagy and obesity and diabetes. Adv. Exp. Med. Biol. 2020, 1207, 445-461. [CrossRef] [PubMed]

116. Kim, J.; Lim, Y.-M.; Lee, M.-S. The role of autophagy in systemic metabolism and human-type diabetes. Mol. Cells 2018, 41, 11-17. [CrossRef] [PubMed]

117. Lin, T.-A.; Wu, V.C.-C.; Wang, C.-Y. Autophagy in chronic kidney diseases. Cells 2019, 8, 61. [CrossRef]

118. Yang, D.; Livingston, M.J.; Liu, Z.; Dong, G.; Zhang, M.; Chen, J.-K.; Dong, Z. Autophagy in Diabetic kidney disease: Regulation, pathological role and therapeutic potential. Cell. Mol. Life Sci. 2018, 75, 669-688. [CrossRef]

119. Korbut, A.I.; Taskaeva, I.S.; Bgatova, N.P.; Muraleva, N.A.; Orlov, N.B.; Dashkin, M.V.; Khotskina, A.S.; Zavyalov, E.L.; Konenkov, V.I.; Klein, T.; et al. SGLT2 inhibitor empagliflozin and DPP4 inhibitor linagliptin reactivate glomerular autophagy in Db/Db mice, a model of type 2 diabetes. Int. J. Mol. Sci. 2020, 21, 2987. [CrossRef]

120. Efeyan, A.; Comb, W.C.; Sabatini, D.M. Nutrient-sensing mechanisms and pathways. Nature 2015, 517, 302-310. [CrossRef]

121. Klionsky, D.J.; Abdel-Aziz, A.K.; Abdelfatah, S.; Abdellatif, M.; Abdoli, A.; Abel, S.; Abeliovich, H.; Abildgaard, M.H.; Abudu, Y.P.; Acevedo-Arozena, A.; et al. Guidelines for the use and interpretation of assays for monitoring autophagy (4th edition). Autophagy 2021, 17, 1-382. [CrossRef]

122. King, K.E.; Losier, T.T.; Russell, R.C. Regulation of autophagy enzymes by nutrient signaling. Trends Biochem. Sci. 2021. [CrossRef] [PubMed]

123. Condon, K.J.; Sabatini, D.M. Nutrient regulation of MTORC1 at a glance. J. Cell Sci. 2019, 132. [CrossRef] [PubMed]

124. Zhang, N.; Zhao, Y. Other molecular mechanisms regulating autophagy. Adv. Exp. Med. Biol. 2019, 1206, 261-271. [PubMed]

125. Elhassan, S.A.M.; Candasamy, M.; Chan, E.W.L.; Bhattamisra, S.K. Autophagy and GLUT4: The missing pieces. Diabetes Metab. Syndr. 2018, 12, 1109-1116. [CrossRef] [PubMed]

126. Zhao, H.; Tang, M.; Liu, M.; Chen, L. Glycophagy: An emerging target in pathology. Clin. Chem. Acta 2018, 484, 298-303. [CrossRef] [PubMed] 
127. Zhang, W.; Song, J.; Zhang, Y.; Ma, Y.; Yang, J.; He, G.; Chen, S. Intermittent high glucose-induced oxidative stress modulates retinal pigmented epithelial cell autophagy and promotes cell survival via increased HMGB1. BMC Ophthalmol. 2018, 18, 192. [CrossRef] [PubMed]

128. Ren, Y.; Tao, S.; Zheng, S.; Zhao, M.; Zhu, Y.; Yang, J.; Wu, Y. Salvianolic acid B improves vascular endothelial function in diabetic rats with blood glucose fluctuations via suppression of endothelial cell apoptosis. Eur. J. Pharmacol. 2016, 791, 308-315. [CrossRef] [PubMed]

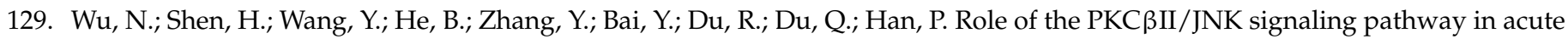
glucose fluctuation-induced apoptosis of rat vascular endothelial cells. Acta Diabetol. 2017, 54, 727-736. [CrossRef]

130. Ying, C.; Wang, S.; Lu, Y.; Chen, L.; Mao, Y.; Ling, H.; Cheng, X.; Zhou, X. Glucose fluctuation increased mesangial cell apoptosis related to akt signal pathway. Arch. Med. Sci. 2019, 15, 730-737. [CrossRef]

131. Chai, Q.; Miao, J.; Liu, M.; Zhang, Z.; Meng, Z.; Wu, W. SGLT1 Knockdown prevents glucose fluctuation-induced apoptosis of cardiomyocytes through attenuating oxidative stress and mitochondrial dysfunction. Biochem. Cell Biol. 2020. [CrossRef]

132. Wang, H.; Deng, J.; Chen, L.; Ding, K.; Wang, Y. Acute glucose fluctuation induces inflammation and neurons apoptosis in hippocampal tissues of diabetic rats. J. Cell. Biochem. 2019. [CrossRef]

133. Yan, T.; Zhang, Z.; Li, D. NGF Receptors and PI3K/AKT pathway involved in glucose fluctuation-induced damage to neurons and $\alpha$-lipoic acid treatment. BMC Neurosci. 2020, 21, 38. [CrossRef]

134. Hsieh, C.-F.; Liu, C.-K.; Lee, C.-T.; Yu, L.-E.; Wang, J.-Y. Acute glucose fluctuation impacts microglial activity, leading to inflammatory activation or self-degradation. Sci. Rep. 2019, 9, 840. [CrossRef]

135. Xue, B.; Wang, L.; Zhang, Z.; Wang, R.; Xia, X.-X.; Han, P.-P.; Cao, L.-J.; Liu, Y.-H.; Sun, L.-Q. Puerarin may protect against schwann cell damage induced by glucose fluctuation. J. Nat. Med. 2017, 71, 472-481. [CrossRef]

136. Alnahdi, A.; John, A.; Raza, H. Mitigation of glucolipotoxicity-induced apoptosis, mitochondrial dysfunction, and metabolic stress by $\mathrm{N}$-acetyl cysteine in pancreatic $\beta$-cells. Biomolecules 2020, 10, 239. [CrossRef]

137. Rani, K.; Aung, N.Y. Docosahexaenoic acid inhibits vascular smooth muscle cell proliferation induced by glucose variability. Open Biochem. J. 2017, 11, 56-65. [CrossRef] [PubMed]

138. Yu, S.H.; Yu, J.M.; Yoo, H.J.; Lee, S.J.; Kang, D.H.; Cho, Y.J.; Kim, D.M. Anti-proliferative effects of rutin on OLETF rat vascular smooth muscle cells stimulated by glucose variability. Yonsei Med. J. 2016, 57, 373-381. [CrossRef] [PubMed]

139. Zhang, Z.; Li, J.; Jiang, X.; Yang, L.; Lei, L.; Cai, D.; Zhang, H.; Chen, H. GLP-1 Ameliorates the proliferation activity of INS-1 cells inhibited by intermittent high glucose concentrations through the regulation of cyclins. Mol. Med. Rep. 2014, 10, 683-688. [CrossRef] [PubMed]

140. Chhabra, N.F.; Amarie, O.V.; Wu, M.; Amend, A.-L.; Rubey, M.; Gradinger, D.; Irmler, M.; Beckers, J.; Rathkolb, B.; Wolf, E.; et al. PAX6 mutation alters circadian rhythm and $\beta$ cell function in mice without affecting glucose tolerance. Commun. Biol. 2020, 3, 628. [CrossRef] [PubMed]

141. Yin, Q.; Ni, Q.; Wang, Y.; Zhang, H.; Li, W.; Nie, A.; Wang, S.; Gu, Y.; Wang, Q.; Ning, G. Raptor determines $\beta$-cell identity and plasticity independent of hyperglycemia in mice. Nat. Commun. 2020, 11, 2538. [CrossRef]

142. Kiss, K.; Baghy, K.; Spisák, S.; Szanyi, S.; Tulassay, Z.; Zalatnai, A.; Löhr, J.-M.; Jesenofsky, R.; Kovalszky, I.; Firneisz, G. Chronic hyperglycemia induces trans-differentiation of human pancreatic stellate cells and enhances the malignant molecular communication with human pancreatic cancer cells. PLoS ONE 2015, 10, e0128059. [CrossRef]

143. Regnell, S.E.; Hessner, M.J.; Jia, S.; Åkesson, L.; Stenlund, H.; Moritz, T.; La Torre, D.; Lernmark, Å. Longitudinal analysis of hepatic transcriptome and serum metabolome demonstrates altered lipid metabolism following the onset of hyperglycemia in spontaneously diabetic biobreeding rats. PLoS ONE 2017, 12, e0171372. [CrossRef]

144. Felisbino, M.B.; Ziemann, M.; Khurana, I.; Okabe, J.; Al-Hasani, K.; Maxwell, S.; Harikrishnan, K.N.; de Oliveira, C.B.M.; Mello, M.L.S.; El-Osta, A. Valproic acid influences the expression of genes implicated with hyperglycaemia-induced complement and coagulation pathways. Sci. Rep. 2021, 11, 2163. [CrossRef]

145. Silambarasan, M.; Tan, J.R.; Karolina, D.S.; Armugam, A.; Kaur, C.; Jeyaseelan, K. MicroRNAs in hyperglycemia induced endothelial cell dysfunction. Int. J. Mol. Sci. 2016, 17, 518. [CrossRef]

146. Aas, V.; Hessvik, N.P.; Wettergreen, M.; Hvammen, A.W.; Hallén, S.; Thoresen, G.H.; Rustan, A.C. Chronic hyperglycemia reduces substrate oxidation and impairs metabolic switching of human myotubes. Biochim. Biophys. Acta 2011, 1812, 94-105. [CrossRef]

147. Puri, K.; Lal, N.; Shang, R.; Ghosh, S.; Flibotte, S.; Dyer, R.; Hussein, B.; Rodrigues, B. Diabetes mellitus severity and a switch from using lipoprotein lipase to adipose-derived fatty acid results in a cardiac metabolic signature that embraces cell death. J. Am. Heart Assoc. 2019, 8, e014022. [CrossRef]

148. Maier, K.G.; Han, X.; Sadowitz, B.; Gentile, K.L.; Middleton, F.A.; Gahtan, V. Thrombospondin-1: A proatherosclerotic protein augmented by hyperglycemia. J. Vasc. Surg. 2010, 51, 1238-1247. [CrossRef] [PubMed]

149. Hien, T.T.; Turczyńska, K.M.; Dahan, D.; Ekman, M.; Grossi, M.; Sjögren, J.; Nilsson, J.; Braun, T.; Boettger, T.; Garcia-Vaz, E.; et al Elevated glucose levels promote contractile and cytoskeletal gene expression in vascular smooth muscle via rho/protein kinase C and actin polymerization. J. Biol. Chem. 2016, 291, 3552-3568. [CrossRef] [PubMed]

150. Rønningen, T.; Shah, A.; Reiner, A.H.; Collas, P.; Moskaug, J.Ø. Epigenetic priming of inflammatory response genes by high glucose in adipose progenitor cells. Biochem. Biophys. Res. Commun. 2015, 467, 979-986. [CrossRef] [PubMed]

151. Rubin, A.; Salzberg, A.C.; Imamura, Y.; Grivitishvilli, A.; Tombran-Tink, J. Identification of novel targets of diabetic nephropathy and pedf peptide treatment using RNA-Seq. BMC Genom. 2016, 17, 936. [CrossRef] 
152. Shrestha, S.; Singhal, S.; Sens, D.A.; Somji, S.; Davis, B.A.; Guyer, R.; Breen, S.; Kalonick, M.; Garrett, S.H. Elevated glucose represses lysosomal and MTOR-related genes in renal epithelial cells composed of progenitor CD133+ cells. PLoS ONE 2021, 16, e0248241. [CrossRef] [PubMed]

153. Friedrichs, P.; Schlotterer, A.; Sticht, C.; Kolibabka, M.; Wohlfart, P.; Dietrich, A.; Linn, T.; Molema, G.; Hammes, H.-P. Hyperglycaemic memory affects the neurovascular unit of the retina in a diabetic mouse model. Diabetologia 2017, 60, 1354-1358. [CrossRef]

154. Fan, S.; Yang, Z.; Liu, Y.; Zhong, J.; Zhang, S.; Xiao, Y.; Liu, X.; Yi, W.; He, C.; Hu, Y.; et al. Extensive Sub-RPE complement deposition in a nonhuman primate model of early-stage diabetic retinopathy. Invest. Ophthalmol. Vis. Sci. 2021, 62, 30. [CrossRef] [PubMed]

155. Moganti, K.; Li, F.; Schmuttermaier, C.; Riemann, S.; Klüter, H.; Gratchev, A.; Harmsen, M.C.; Kzhyshkowska, J. Hyperglycemia induces mixed M1/M2 cytokine profile in primary human monocyte-derived macrophages. Immunobiology 2017, 222, 952-959. [CrossRef]

156. Thiem, K.; Keating, S.T.; Netea, M.G.; Riksen, N.P.; Tack, C.J.; van Diepen, J.; Stienstra, R. Hyperglycemic memory of innate immune cells promotes in vitro proinflammatory responses of human monocytes and murine macrophages. J. Immunol. 2021, 206, 807-813. [CrossRef] [PubMed]

157. Zhong, L.; D’Urso, A.; Toiber, D.; Sebastian, C.; Henry, R.E.; Vadysirisack, D.D.; Guimaraes, A.; Marinelli, B.; Wikstrom, J.D.; Nir, T.; et al. The histone deacetylase Sirt6 regulates glucose homeostasis via Hif1alpha. Cell 2010, 140, 280-293. [CrossRef] [PubMed]

158. Emery, M.; Nanchen, N.; Preitner, F.; Ibberson, M.; Roduit, R. Biological characterization of gene response to insulin-induced hypoglycemia in mouse retina. PLoS ONE 2016, 11, e0150266. [CrossRef]

159. Kim, J.L.; La Gamma, E.F.; Estabrook, T.; Kudrick, N.; Nankova, B.B. Whole genome expression profiling associates activation of unfolded protein response with impaired production and release of epinephrine after recurrent hypoglycemia. PLoS ONE 2017, 12, e0172789. [CrossRef]

160. Zervou, S.; Wang, Y.-F.; Laiho, A.; Gyenesei, A.; Kytömäki, L.; Hermann, R.; Abouna, S.; Epstein, D.; Pelengaris, S.; Khan, M. Short-term hyperglycaemia causes non-reversible changes in arterial gene expression in a fully "switchable" in vivo mouse model of diabetes. Diabetologia 2010, 53, 2676-2687. [CrossRef]

161. Saik, O.V.; Klimontov, V.V. Bioinformatic reconstruction and analysis of gene networks related to glucose variability in diabetes and its complications. IJMS 2020, 21, 8691. [CrossRef]

162. El-Osta, A.; Brasacchio, D.; Yao, D.; Pocai, A.; Jones, P.L.; Roeder, R.G.; Cooper, M.E.; Brownlee, M. Transient high glucose causes persistent epigenetic changes and altered gene expression during subsequent normoglycemia. J. Exp. Med. 2008, 205, $2409-2417$. [CrossRef]

163. Costantino, S.; Paneni, F.; Battista, R.; Castello, L.; Capretti, G.; Chiandotto, S.; Tanese, L.; Russo, G.; Pitocco, D.; Lanza, G.A.; et al. Impact of glycemic variability on chromatin remodeling, oxidative stress, and endothelial dysfunction in patients with type 2 diabetes and with target $\mathrm{HbA1c}$ levels. Diabetes 2017, 66, 2472-2482. [CrossRef]

164. Kim, M.; Chung, H.; Yoon, C.; Lee, E.; Kim, T.; Kim, T.; Kwon, M.; Lee, S.; Rhee, B.; Park, J. Increase of INS-1 cell apoptosis under glucose fluctuation and the involvement of FOXO-SIRT pathway. Diabetes Res. Clin. Pract. 2012, 98, 132-139. [CrossRef]

165. Aref-Eshghi, E.; Biswas, S.; Chen, C.; Sadikovic, B.; Chakrabarti, S. Glucose-induced, duration-dependent genome-wide DNA methylation changes in human endothelial cells. Am. J. Physiol. Cell Physiol. 2020, 319, C268-C276. [CrossRef]

166. Abdelzaher, L.A.; Imaizumi, T.; Suzuki, T.; Tomita, K.; Takashina, M.; Hattori, Y. Astaxanthin alleviates oxidative stress insultsrelated derangements in human vascular endothelial cells exposed to glucose fluctuations. Life Sci. 2016, 150, 24-31. [CrossRef]

167. Xiao, X.; Dong, Y.; Zhong, J.; Cao, R.; Zhao, X.; Wen, G.; Liu, J. Adiponectin protects endothelial cells from the damages induced by the intermittent high level of glucose. Endocrine 2011, 40, 386-393. [CrossRef]

168. Thomas, M.C. Glycemic exposure, glycemic control, and metabolic karma in diabetic complications. Adv. Chronic Kidney Dis. 2014, 21, 311-317. [CrossRef] [PubMed]

169. Huang, Y.; Liao, Z.; Lin, X.; Wu, X.; Chen, X.; Bai, X.; Zhuang, Y.; Yang, Y.; Zhang, J. Overexpression of MiR-146a Might regulate polarization transitions of BV-2 cells induced by high glucose and glucose fluctuations. Front. Endocrinol. 2019, 10, 719. [CrossRef] [PubMed]

170. Wang, B.; Li, Y.; You, C. MiR-129-3p targeting of MCU Protects against glucose fluctuation-mediated neuronal damage via a mitochondrial-dependent intrinsic apoptotic pathway. Diabetes Metab. Syndr. Obes. 2021, 14, 153-163. [CrossRef] [PubMed]

171. La Sala, L.; Cattaneo, M.; De Nigris, V.; Pujadas, G.; Testa, R.; Bonfigli, A.R.; Genovese, S.; Ceriello, A. Oscillating glucose induces MicroRNA-185 and impairs an efficient antioxidant response in human endothelial cells. Cardiovasc. Diabetol. 2016, 15, 71. [CrossRef] [PubMed]

172. Cooper, M.E.; El-Osta, A. Epigenetics: Mechanisms and implications for diabetic complications. Circ. Res. 2010, 107, 1403-1413. [CrossRef]

173. Akil, A.-S.A.-S.; Jerman, L.F.; Yassin, E.; Padmajeya, S.S.; Al-Kurbi, A.; Fakhro, K.A. Reading between the (Genetic) lines: How epigenetics is unlocking novel therapies for type 1 diabetes. Cells 2020, 9, 2403. [CrossRef]

174. Luo, X.; Wu, J.; Jing, S.; Yan, L.-J. Hyperglycemic stress and carbon stress in diabetic glucotoxicity. Aging Dis. 2016, 7, 90-110. [CrossRef]

175. Suryavanshi, S.V.; Kulkarni, Y.A. NF-K $\beta$ : A potential target in the management of vascular complications of diabetes. Front. Pharmacol. 2017, 8, 798. [CrossRef] [PubMed] 
176. Chen, G.; Chen, Y.; Chen, H.; Li, L.; Yao, J.; Jiang, Q.; Lin, X.; Wen, J.; Lin, L. The effect of NF-KB pathway on proliferation and apoptosis of human umbilical vein endothelial cells induced by intermittent high glucose. Mol. Cell Biochem. 2011, 347, 127-133. [CrossRef] [PubMed]

177. Zhang, Z.-Y.; Qian, L.-L.; Wang, N.; Miao, L.-F.; Ma, X.; Dang, S.-P.; Wu, Y.; Liu, X.-Y.; Li, X.-Y.; Chai, Q.; et al. Glucose fluctuations promote vascular BK channels dysfunction via PKC $\alpha / \mathrm{NF}-\mathrm{KB} / \mathrm{MuRF1}$ signaling. J. Mol. Cell. Cardiol. 2020, 145, 14-24. [CrossRef]

178. Schultze, S.M.; Hemmings, B.A.; Niessen, M.; Tschopp, O. PI3K/AKT, MAPK and AMPK Signalling: Protein kinases in glucose homeostasis. Expert Rev. Mol. Med. 2012, 14, e1. [CrossRef]

179. Zhang, Z.-Y.; Miao, L.-F.; Qian, L.-L.; Wang, N.; Qi, M.-M.; Zhang, Y.-M.; Dang, S.-P.; Wu, Y.; Wang, R.-X. Molecular mechanisms of glucose fluctuations on diabetic complications. Front. Endocrinol. 2019, 10, 640. [CrossRef]

180. Zhang, W.; Liu, H.T. MAPK signal pathways in the regulation of cell proliferation in mammalian cells. Cell Res. 2002, 12, 9-18. [CrossRef]

181. Evans, J.L.; Goldfine, I.D.; Maddux, B.A.; Grodsky, G.M. Are oxidative stress-activated signaling pathways mediators of insulin resistance and -cell dysfunction? Diabetes 2003, 52, 1-8. [CrossRef]

182. Yarza, R.; Vela, S.; Solas, M.; Ramirez, M.J. C-Jun N-terminal kinase (JNK) Signaling as a therapeutic target for Alzheimer's disease. Front. Pharmacol. 2016, 6. [CrossRef] [PubMed]

183. Bretón-Romero, R.; Feng, B.; Holbrook, M.; Farb, M.G.; Fetterman, J.L.; Linder, E.A.; Berk, B.D.; Masaki, N.; Weisbrod, R.M.; Inagaki, E.; et al. Endothelial dysfunction in human diabetes is mediated by Wnt5a-JNK signaling. Arter. Thromb. Vasc. Biol. 2016, 36, 561-569. [CrossRef] [PubMed]

184. Tang, Z.; Lei, M. Involvement of JNK signal transduction pathway in endothelial cell apoptosis induced by intermittent high glucose. Zhong Nan Da Xue Xue Bao. Yi Xue Ban 2010, 35, 616-621. [CrossRef] [PubMed]

185. Zhang, Z.-Y.; Wang, N.; Qian, L.-L.; Miao, L.-F.; Dang, S.-P.; Wu, Y.; Wang, R.-X. Glucose fluctuations promote aortic fibrosis through the ROS/P38 MAPK/Runx2 signaling pathway. J. Vasc. Res. 2020, 57, 24-33. [CrossRef]

186. Lan, H.Y.; Chung, A.C.K. Transforming growth factor- $\beta$ and smads. Contrib. Nephrol. 2011, 170, 75-82. [CrossRef] [PubMed]

187. Chen, K.-H.; Hung, C.-C.; Hsu, H.-H.; Jing, Y.-H.; Yang, C.-W.; Chen, J.-K. Resveratrol ameliorates early diabetic nephropathy associated with suppression of augmented TGF- $\beta /$ Smad and ERK1/2 signaling in streptozotocin-induced diabetic rats. Chem. Biol. Interact. 2011, 190, 45-53. [CrossRef] [PubMed]

188. Cheng, X.; Gao, W.; Dang, Y.; Liu, X.; Li, Y.; Peng, X.; Ye, X. Both ERK/MAPK and TGF-Beta/Smad signaling pathways play a role in the kidney fibrosis of diabetic mice accelerated by blood glucose fluctuation. J. Diabetes Res. 2013, 2013, 463740. [CrossRef]

189. Ye, X.; Cheng, X.; Liu, L.; Zhao, D.; Dang, Y. Blood glucose fluctuation affects skin collagen metabolism in the diabetic mouse by inhibiting the mitogen-activated protein kinase and smad pathways. Clin. Exp. Dermatol. 2013, 38, 530-537. [CrossRef] [PubMed]

190. Jeon, S.-M. Regulation and function of AMPK in physiology and diseases. Exp. Mol. Med. 2016, 48, e245. [CrossRef]

191. González, A.; Hall, M.N.; Lin, S.-C.; Hardie, D.G. AMPK and TOR: The yin and yang of cellular nutrient sensing and growth control. Cell Metab. 2020, 31, 472-492. [CrossRef] [PubMed]

192. Jiang, P.; Ren, L.; Zhi, L.; Yu, Z.; Lv, F.; Xu, F.; Peng, W.; Bai, X.; Cheng, K.; Quan, L.; et al. Negative regulation of AMPK signaling by high glucose via E3 ubiquitin ligase MG53. Mol. Cell 2021, 81, 629-637.e5. [CrossRef] [PubMed]

193. Zhao, H.-Y.; Zhao, M.; Yi, T.-N.; Zhang, J. Globular adiponectin protects human umbilical vein endothelial cells against apoptosis through adiponectin receptor 1/adenosine monophosphate-activated protein kinase pathway. Chin. Med. J. 2011, 124, $2540-2547$. [PubMed]

194. Gleason, C.E.; Lu, D.; Witters, L.A.; Newgard, C.B.; Birnbaum, M.J. The role of AMPK and MTOR in nutrient sensing in pancreatic beta-cells. J. Biol. Chem. 2007, 282, 10341-10351. [CrossRef] [PubMed]

195. Leprivier, G.; Rotblat, B. How does MTOR sense glucose starvation? AMPK is the usual suspect. Cell Death Discov. 2020, 6, 27. [CrossRef] [PubMed]

196. Li, M.; Zhang, C.-S.; Feng, J.-W.; Wei, X.; Zhang, C.; Xie, C.; Wu, Y.; Hawley, S.A.; Atrih, A.; Lamont, D.J.; et al. Aldolase is a sensor for both low and high glucose, linking to AMPK and MTORC1. Cell Res. 2021, 31, 478-481. [CrossRef]

197. Ali, M.; Bukhari, S.A.; Ali, M.; Lee, H.-W. Upstream signalling of MTORC1 and its hyperactivation in type 2 diabetes (T2D). BMB Rep. 2017, 50, 601-609. [CrossRef] [PubMed]

198. Chong, Z.; Maiese, K. Mammalian target of rapamycin signaling in diabetic cardiovascular disease. Cardiovasc. Diabetol. 2012, 11, 45. [CrossRef]

199. Liu, Y.; Zheng, Y.; Zhou, Y.; Liu, Y.; Xie, M.; Meng, W.; An, M. The expression and significance of MTORC1 in diabetic retinopathy. BMC Ophthalmol. 2020, 20, 297. [CrossRef]

200. Yasuda-Yamahara, M.; Kume, S.; Maegawa, H. Roles of MTOR in diabetic kidney disease. Antioxidants 2021, 10, 321. [CrossRef] 